\title{
Socioeconomic Deprivation, Adverse Childhood Experiences and Medical Disorders in Adulthood: Mechanisms and Associations
}

\author{
Gerwyn Morris $^{1} \cdot$ Michael Berk $^{1,2,3,4} \cdot$ Michael Maes $^{1,5} \cdot$ André F. Carvalho $^{6,7} \cdot$ Basant K. Puri $^{8}$ (D)
}

Received: 10 November 2018 / Accepted: 15 January 2019 / Published online: 26 January 2019

(C) The Author(s) 2019

\begin{abstract}
Severe socioeconomic deprivation (SED) and adverse childhood experiences (ACE) are significantly associated with the development in adulthood of (i) enhanced inflammatory status and/or hypothalamic-pituitary-adrenal (HPA) axis dysfunction and (ii) neurological, neuroprogressive, inflammatory and autoimmune diseases. The mechanisms by which these associations take place are detailed. The two sets of consequences are themselves strongly associated, with the first set likely contributing to the second. Mechanisms enabling bidirectional communication between the immune system and the brain are described, including complex signalling pathways facilitated by factors at the level of immune cells. Also detailed are mechanisms underpinning the association between SED, ACE and the genesis of peripheral inflammation, including epigenetic changes to immune system-related gene expression. The duration and magnitude of inflammatory responses can be influenced by genetic factors, including single nucleotide polymorphisms, and by epigenetic factors, whereby pro-inflammatory cytokines, reactive oxygen species, reactive nitrogen species and nuclear factor- $\mathrm{kB}$ affect gene DNA methylation and histone acetylation and also induce several microRNAs including miR-155, miR-181b-1 and miR-146a. Adult HPA axis activity is regulated by (i) genetic factors, such as glucocorticoid receptor polymorphisms; (ii) epigenetic factors affecting glucocorticoid receptor function or expression, including the methylation status of alternative promoter regions of $\mathrm{NR} 3 \mathrm{Cl}$ and the methylation of FKBP5 and HSD11 $\beta 2$; (iii) chronic inflammation and chronic nitrosative and oxidative stress. Finally, it is shown how severe psychological stress adversely affects mitochondrial structure and functioning and is associated with changes in brain mitochondrial DNA copy number and transcription; mitochondria can act as couriers of childhood stress into adulthood.
\end{abstract}

Keywords Adverse childhood experiences · Gene expression · Hypothalamic-pituitary-adrenal axis · Immune system · Mitochondria $\cdot$ Socioeconomic deprivation

\section{Introduction}

There is a large body of research demonstrating the existence of a significant association between severe socioeconomic deprivation (SED) and adverse childhood experiences (ACE) and the development of enhanced inflammatory status

Basant K. Puri

basant.puri@imperial.ac.uk

1 IMPACT Strategic Research Centre, School of Medicine, Deakin University, Barwon Health, P.O. Box 291, Geelong, Victoria, Australia

2 Department of Psychiatry, Level 1 North, Main Block, Royal Melbourne Hospital, University of Melbourne, Parkville, Victoria, Australia

3 Florey Institute for Neuroscience and Mental Health, University of Melbourne, Kenneth Myer Building, 30 Royal Parade, Parkville, Victoria, Australia and/or hypothalamic-pituitary-adrenal (HPA) axis dysfunction in adulthood [1-3]. There are also parallel data demonstrating a positive association between SED and ACE in childhood and the subsequent development of a wide range of neurological, neuroprogressive, inflammatory and autoimmune diseases [1]. The latter association would seem

4 Orygen, The National Centre of Excellence in Youth Mental Health, 35 Poplar Rd, Parkville, Victoria, Australia

5 Department of Psychiatry, Chulalongkorn University, Bangkok, Thailand

6 Department of Psychiatry, Faculty of Medicine, University of Toronto, Toronto, ON, Canada

7 Centre for Addiction \& Mental Health (CAMH), Toronto, ON, Canada

8 Department of Medicine, Hammersmith Hospital, Imperial College London, London, UK 
unsurprising given a wealth of data implicating a role for increased levels of peripheral inflammation and/or HPA axis dysfunction in the pathogenesis and pathophysiology of several of these illnesses [4-6]. Indeed, some form of causal relationship between the inflammatory burden and HPA axis transferred from childhood in the aetiology of these illnesses is suspected $[2,7]$. However, such HPA axis dysfunction and increased inflammatory burden is seen in adults exposed to SED and ACE and adverse experiences in childhood are seen in adults with no discernible evidence of pathology [8-10]. This suggests that other factors determine whether these experiences lead to overt pathology or not.

One concept invoked to explain these observations at least in part is the phenomenon of psychological resilience. Readers interested in an examination of the evidence for and against this explanation are invited to consult recent papers by [11, 12]. Another heuristic invoked in an attempt to explain this central question is the concept of allostatic load and the failure of adaptive mechanisms (allostasis) leading to allostatic overload and the subsequent development of pathology in adulthood or adolescence [13]. Over a lifetime, allostasis and allostatic loads (or pathophysiology) epigenetically affect both central and peripheral processes: stressful phenomena, including environmental stressors, major life events, abuse and trauma, can affect the development of stress susceptibility and lead to epigenetic changes in central neural circuitry and functioning; in turn, this can feed into perceived stress, in terms of vigilance and helplessness [13]. This, in turn, is associated with behavioural and physiological responses which mediate allostasis, leading to adaptation; as a result of, for example, repeated stress or dysregulated stress responses (that is, allostatic load), it has been argued that this can lead to pathophysiology [13].

Recent data suggest that the extent of allostatic load appears to be determined by defects in the responses of the autonomic nervous system and the HPA axis as well as increasing levels of lipids and glucose and the extent of inflammation, nitrosative and oxidative stress and mitochondrial dysfunction in any given individual $[14,15]$ (reviewed in [16]).

Genetic and epigenetic elements influence all the elements comprising allostatic load as discussed above. For example the weight of evidence indicates that polymorphisms in cytokine and/or Toll-like receptor (TLR) genes and other variations in the genome and epigenome may influence the magnitude and duration of inflammatory responses to cellular stimuli and the subsequent levels of oxidative stress [17-20]. Abnormalities in the epigenetic regulation of the activity of these and other genes can have similar consequences [21]. Epigenetic and genetic factors also influence the performance of mitochondria $[22,23]$. Mitochondrial function also affects lipid and glucose levels in any given individual (reviewed in [24, 25]). Mitochondrial dysfunction alone and in combination with raised lipid and glucose levels can also add to the burden of inflammation and oxidative stress in the periphery and the brain [26-28]. Predictably, the response of the neuroendocrine system and the HPA axis to severe and or prolonged psychosocial stress is also under genetic and epigenetic influences [13, $29,30]$ and the abnormal performance of both systems can make an independent contribution to whole body increases in inflammation oxidative stress and indeed mitochondrial dysfunction $[1,31]$. It should also be noted that increased levels of inflammation, oxidative stress and mitochondrial dysfunction can conspire to provoke epigenetic dysregulation via altered levels of DNA methylation, histone modifications (such as acetylation) and microRNA (miRNA) synthesis [23, 32-34].

These are important observations, as high levels of inflammation and oxidative stress can induce tissue damage and the formation of damage-associated molecular patterns (DAMPs) which can engage with pattern recognition receptors (PRRs) on antigen-presenting cells (APCs) with the production of pro-inflammatory cytokines (PICs) and reactive oxygen species (ROS), thus maintaining and indeed amplifying a chronic state of peripheral inflammation, nitrosative and oxidative stress and mitochondrial dysfunction [35, 36]. There is also evidence that such a state in the periphery can lead to the activation of microglia and astrocytes in the brain leading to the development of chronic neuroinflammation with increased levels of ROS in the brain together with a stream of other neurotoxic consequences such as disturbance to neurotransmission and neuron to glial cell communication known to contribute to the development of neuropsychiatric and neurodegenerative conditions $[6,37]$. It should also be noted that activation of these glial cells and the neuropathology stemming from such activation can be induced by stress-related increase in glucocorticoid (GC) levels in the CNS even in the absence of peripheral inflammation [38-40]. This level of chronic inflammation can inhibit HPA axis activity, which may also be inhibited more directly by GC resistance, including glucocorticoid receptor (GR) methylation [30, 41].

When considered as a whole, there is considerable evidence in support of the proposition that the allostatic load experienced during childhood can inhibit allostasis leading to the development of allostatic overload in adulthood in the context of genetic and or epigenetic vulnerability. There is also growing evidence that the "unholy trinity" of mitochondrial dysfunction, nitrosative and oxidative stress and inflammation may well be the most significant contributors to allostatic load [14]. A detailed consideration of the mechanisms underpinning the origin of this triad in at least some children subjected to such adverse environmental conditions and their overall detrimental influence on the other mediators of allostasis and the persistence of such abnormalities into adulthood is the main focus of this paper.

Much of the early research in this area has been focused on the bidirectional interaction between peripheral inflammation resulting from PIC release by APCs in the periphery as part of an evolutionary response to environmental stressors and the 
neuroendocrine system. Hence, we will consider such research in the first section before going on to consider more recent findings regarding the importance of oxidative stress in the brain and mitochondrial dysfunction. First, however, it seems appropriate to review the quality and quantity of evidence demonstrating an association between the experience of SED and other ACE in childhood and the development of neuropsychiatric, neurodegenerative and autoimmune illnesses in adulthood.

\section{Childhood SED and/or ACE and the Development of IIInesses in Adulthood}

\section{Overview}

There is a large and accumulating body of evidence demonstrating an association between adverse socioeconomic or caregiving experiences in childhood and increased risk of morbidity and mortality from non-communicable chronic health problems in adulthood [42-44], including rheumatoid arthritis (RA), systemic lupus erythematosus (SLE), Sjögren's syndrome, cardiovascular disease, diabetes, hypertension, chronic fatigue syndrome (CFS) fibromyalgia, Alzheimer's disease (AD), Parkinson's disease, amyotrophic lateral sclerosis (ALS), major depressive disorder (MDD), anxiety, cancer and all causes of premature mortality [43, 45-51]. It is also noteworthy that many authors have reported that such an association persists even in the face of significant increases in the quality of life experienced by individuals during adolescence and adulthood $[52,53]$.

\section{SED, ACE and the Development of Chronic Inflammation}

Several, mainly cross-sectional, studies have demonstrated that environmental and socioeconomic adversity in childhood is associated with significantly increased levels of systemic inflammation in both childhood [54-56] and adulthood [9, 31, 57-59]. It seems worthy of note that lower education and income appear to be particular factors associated with the development of an inflammatory burden in adulthood $[8,57$, 60-62]. Such inflammatory activity is evidenced by significantly elevated levels of the inflammatory markers C-reactive protein (CRP) [63, 64], IL-6 [60, 61, 65], TNF- $\alpha$ [57, 65], IL-2 $[57,65]$ and NF-KB $[66,67]$. Unsurprisingly, recent studies using a life course approach identified inflammation markers as at least in part explaining social differences in health [68, 69]. Additional studies revealed that both early life and adult adverse socioeconomic circumstances have the potential to alter inflammation status [70, 71]. It should be emphasised however that the results in this area are heavily influenced by study design as we will now move on to consider.

\section{Study Design Effects Regarding SED, ACE and Increased Risk of Adult Illness}

Socioeconomic status (SES) is a mediator, marker and moderator of diverse other operative variables [72]. Prospective studies investigating correlations between low SES in childhood and increases in single markers of inflammation in adulthood have reported weakly significant or non-significant associations following adjustment for other variables such as ethnicity, adult SES, body mass index or educational status [49, 72-74]. However, a longitudinal study performed by Castagne and fellow workers examining the levels of a wide range of cytokines and chemokines using multiplex technology reported a significant association between low childhood SES and adult inflammatory status, although the increases in cytokine and chemokine levels compared with adults who had a benign childhood economic status were modest [2]. This association has been confirmed in the prospective Brazilian Longitudinal Study of Adult Health (ELSA-Brasil) involving 13,371 civil servants [75]. These authors reported a linear increase in the inflammatory marker CRP with an increasing number of adverse socioeconomic circumstances throughout the individual's life course [75]. These findings were replicated in the Jerusalem Perinatal Family Follow-Up Study by [76] involving follow-up examinations of 1,132 offspring of all the births in Jerusalem between 1974 and 1976. The authors established that adult and childhood economic status were independent contributors to adult inflammatory status [76]. A similar pattern emerged from studies investigating the relationship between other childhood stressors such as maltreatment and adult inflammatory status. A meta-analysis of 60 retrospective cross-sectional studies examining this phenomenon involving 16,870 participants conducted by Baumeister and fellow workers concluded that childhood mistreatment was significantly associated with a modest increase in CRP, TNF- $\alpha$ and IL-6 levels, although the association with increased CRP was stronger than for the cytokines [77]. This supported the conclusions of an earlier prospective study conducted over 20 years which demonstrated that childhood maltreatment was independently associated with modestly increased levels of CRP, IL- 6 and TNF- $\alpha$ in adulthood [63].

\section{SED, ACE and the Development of HPA Axis Dysfunction in Adulthood}

\section{Evidence Associating SED, ACE and Dysfunction of HPA Axis Activity}

There is a considerable body of evidence indicating that children from disadvantaged backgrounds experiencing environmental stressors such as low SES and poor housing conditions are significantly more likely to display evidence of persistent 
HPA axis dysregulation [78-81]. In addition, the weight of evidence suggests that the aggregate effect of SED and $\mathrm{ACE}$, rather than the impact of individual risks, is deterministic of pathological outcomes (reviewed in [3]). A comprehensive meta-analysis of 26 cross-sectional studies examining the association between SES and cortisol levels conducted by Dowd and fellow workers concluded that a slightly blunted pattern of diurnal cortisol secretion in association with lower SES was the most consistent observation, although overall there was no consistent association between SES and cortisol levels [82]. Several prospective studies have examined longitudinal changes in HPA axis function in consort with changes in SES over time and have generally reported a negative association between SES and concentrations of cortisol present in hair samples [83-85]. There is a growing consensus that the measurement of hair cortisol levels is the most appropriate method for measuring aggregate concentrations of this molecule over time [86].

\section{HPA Axis Dysfunction and the Development of Adult Diseases}

HPA axis hypofunction in particular is found in illnesses such as RA [87-89], Sjögren's syndrome [90, 91], CFS [92], SLE [93, 94], multiple sclerosis (MS) [95, 96] and MDD [97]. Blunted or deregulated HPA axis activity is also seen in people suffering from chronic pain (reviewed in [98]), chronic fatigue [99] and chronic insomnia [100]. There is also a large body of evidence supporting the concept that severe early-life experiences result in HPA axis dysfunction in adulthood and the development of peripheral inflammation [77]. The HPA axis is also a powerful modulator of inflammatory activity and is in turn modulated by inflammatory processes [7, 30, 101]. The mechanisms underpinning such a bidirectional relationship go some way to explaining how HPA axis dysfunction might contribute to the development of inflammatory diseases in adulthood and hence will be the subject of the next section of the paper.

\section{Mechanisms Enabling Bidirectional Communication Between the Immune System and the Brain}

\section{Overview}

Bidirectional communication between the immune system and the CNS involving highly complex signalling pathways plays an indispensable role in restraining immune and inflammatory responses in physiological and pathological conditions [102]. This communication is facilitated at the level of immune cells by several mechanisms, such as the expression of surface receptors for several different neurotransmitters, allowing the brain to modulate the immune response [103, 104]) and the secretion of opioids and immunomodulatory catecholamines such as noradrenaline (norepinephrine) and adrenaline (epinephrine) and by acetylcholine [103, 105]. Peripheral mononuclear blood cells (PMBCs) also express receptors for a wide array of ligands such as corticosteroids, prolactin, insulin, somatostatin, growth hormone $(\mathrm{GH})$, testosterone, oestrogen, ghrelin, leptin, opioids, neuropeptide $\mathrm{Y}$ and vasoactive intestinal peptide (VIP) [106].

The CNS responses to increased immune activity or the development of inflammation are largely mediated via neuronal and hormonal pathways. The neuronal route is mediated via the autonomic nervous system inflammatory reflex, whereby stimulation of the vagus nerve as an example leads to cholinergic interaction with the $\alpha 7$ subunit of the nicotinic acetylcholine surface receptor ( $\alpha 7 \mathrm{nAChR})$ of splenic macrophages, in turn leading to inhibition of inflammatory cytokine release by these T cells [107-109] (see Fig. 1). Neuroendocrine signalling between the immune system and the CNS is mediated by several discrete axes of interactions such as the HPA, hypothalamic-pituitary-thyroid (HPT), hypothalamic-pituitarygonadal (HPG) and hypothalamic-pituitary-growth hormone axes, with the HPA axis being the most important $[106,110]$.

\section{The Role of Peripheral Inflammation in the Activation of the HPA Axis}

Inflammatory signals can reach the brain via humoral and neural routes to activate the HPA axis [5]. The humoral route involves direct or indirect cytokine signalling either via direct access to the brain via regions where the integrity of the bloodbrain barrier (BBB) is compromised or absent, such as the choroid plexus or other circumventricular organs (CVOs) [37], or by direct entry via saturable transport systems in the BBB or an indirect induction of cytokines and other inflammatory mediators such as prostaglandins and their subsequent release into the CNS parenchyma, or via provocation of an increase in BBB permeability $[111,112]$. The neural route involves direct stimulatory action of PICs on peripheral afferent neurones of the vagus nerve $[113,114]$. A broad array of cytokines such as TNF- $\alpha$, IL-1, IL-6, IL-2 and IFN- $\gamma$ can induce and regulate the HPA axis and, as will be discussed, their levels in turn are also heavily influenced by secretion of GCs [104].

\section{Mechanisms Involved in the Regulation of HPA Axis Activity}

In physiological conditions, HPA axis activity is regulated by a multitude of afferent parasympathetic, sympathetic and limbic circuits such as the hippocampus, amygdala and medial prefrontal cortex which innervate the paraventricular nucleus (PVN) of the hypothalamus via a number of direct or indirect 
Fig. 1 The circuit of the antiinflammatory reflex is enabled by signals carried by the afferent and efferent branches of the vagus nerve. The afferent branch is activated in response to the presence of PICs, DAMPs and PAMPs in peripheral tissues. The efferent signal is communicated via the coeliac ganglion and activates splenic adrenergic neurones inducing the release of noradrenaline (norepinephrine) near acetylcholine secreting $\mathrm{T}$ cells. Released acetylcholine then transverses the marginal zone before entering the red pulp and activating $\alpha 7 \mathrm{nAChR}$ expressed on PIC-secreting macrophages and dendritic cells which then suppresses the release of these and other pro-inflammatory molecules

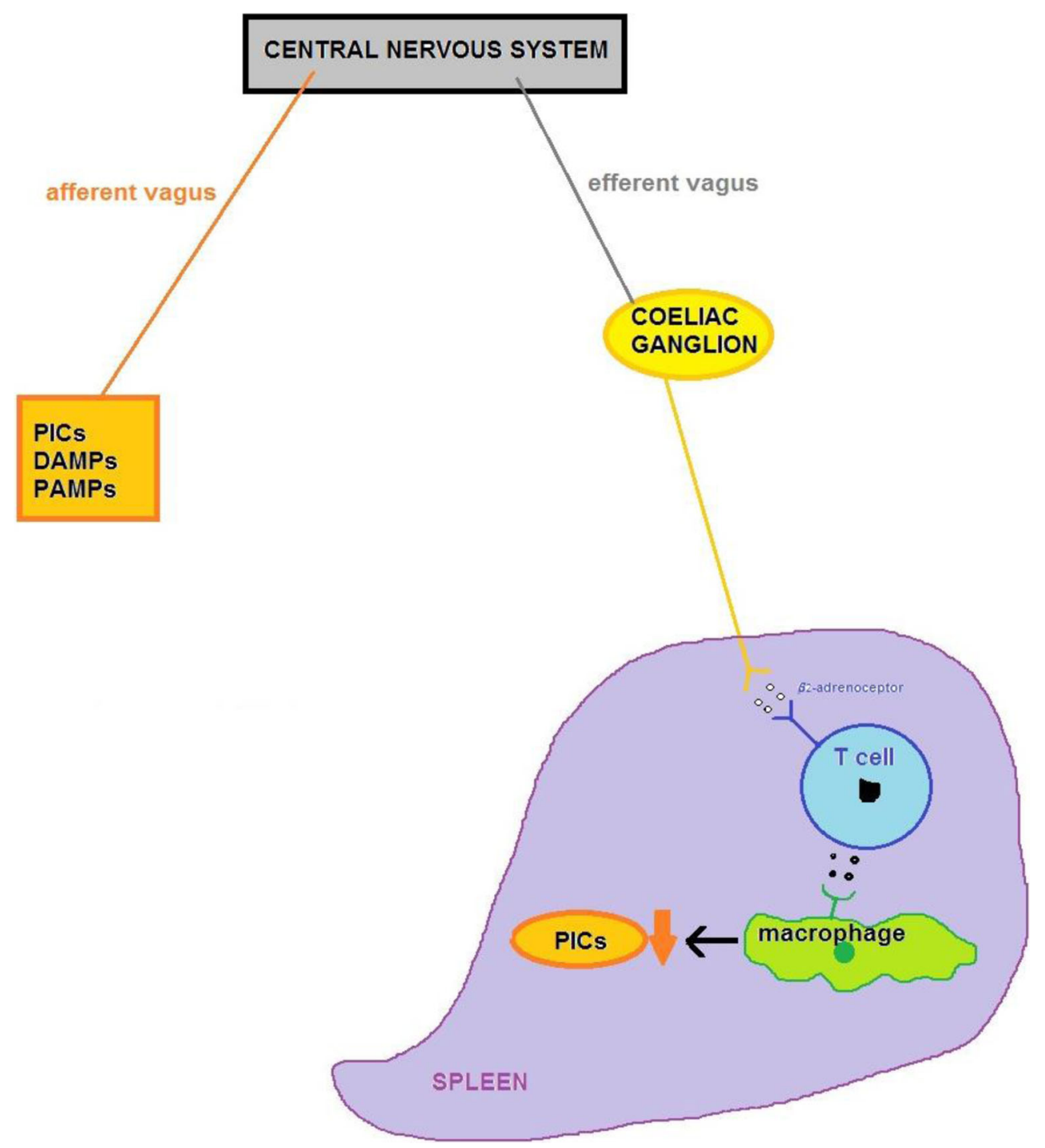

routes (reviewed in [97]). The PVN in turn integrates a number of stimulatory serotonergic, glutamatergic and catecholaminergic and inhibitory GABAergic signals, thereby representing a crucial hub in the regulation of HPA axis activity [115-117]. The activation of the HPA axis occurs following the indirect or direct stimulation of secretory neurones in the medial parvocellular region of the PVN or via the reduction of inhibitory inputs. The increased activity of these neurones leads to the release of corticotrophinreleasing hormone $(\mathrm{CRH})$ and arginine vasopressin (AVP) into, respectively, the portal circulations of the anterior and posterior pituitary gland [7]. CRH in turn provokes the release of adrenocorticotrophic hormone (ACTH) into the systemic circulation by pituitary corticotropes. ACTH then ultimately induces the synthesis and secretion of GCs mainly by the zona fasciculata, and to a lesser extent by the zona reticularis, of the suprarenal (adrenal) cortex, followed by their systemic release $[118,119]$.

\section{Mechanisms Underpinning the Anti-inflammatory Responses of HPA Axis Activation}

The release of GCs results in termination of HPA axis activation, in the absence of pathology, based on negative feedback achieved by the action of GCs on two main receptors, namely the cytosolic GR and the mineralocorticoid receptor (MR) which translocate to the nucleus following ligation [120, 121]. The MR has been described as a "promiscuous receptor" as, in humans, it binds to the mineralocorticoids aldosterone and 11-deoxycorticosterone, the GCs cortisol, 11deoxycortisol and corticosterone, and the sex hormone progesterone (reviewed in [7]). MRs have a far greater affinity for GCs than do GRs (some ten times higher) [122] and are considered to be the principal regulator of circadian cortisol levels [123]. GRs, on the other hand, are considered to play a major role in regulating peak morning cortisol levels owing to their high affinity for dexamethasone and, crucially from the 
perspective of this paper, their role in anti-inflammatory and stress responses (reviewed in [124]).

Binding of a GC to a GR leads to the dissociation of molecular chaperones from the GR. The GC-GR complex then translocates to the cell nucleus where gene expression is regulated by interaction with glucocorticoid response elements and via protein-protein engagement with a range of other transcription factors, such as activator protein 1 (AP-1), nuclear factor- $\mathrm{kB}(\mathrm{NF}-\mathrm{KB})$, nuclear factor of activated $\mathrm{T}$ cell (NFAT) and signal transducer and activator of transcription (STAT) [125-127] (see [128]). The main anti-inflammatory properties of GCs are mediated via the contact-driven suppression of NF- $\mathrm{kB}, \mathrm{AP}-1$ and STAT [129]. However, there is a mutually antagonistic relationship between GRs and these inflammatory transcription factors and there are data demonstrating that NF-KB, STAT and AP-1, which are elevated in inflammatory conditions, can in turn inhibit GR function [101]. The sensitivity of GRs to the action of GCs is also determined by a range of other factors, including GR function, GR number and GR affinity $[129,130]$.

\section{Mechanisms Underpinning the Association Between SED, ACE and the Genesis of Peripheral Inflammation}

Low SES and the resultant multiplicity of chronic stressors in childhood effect epigenetic changes, particularly in the methylation status of DNA, leading to the production of a proinflammatory phenotype in macrophages and in turn causing an exaggerated inflammatory response to the presence of microbial antigens such as bacterial lipopolysaccharide (LPS) in childhood and adulthood [31, 131, 132]. There is also a growing body of evidence suggesting that chronic stressors stemming from SED affect the methylation status of GRs, accessory functional proteins and a range of genes regulating HPA axis activity [1, 31] (reviewed in [133]). Miller and fellow workers reported that exposure to chronic stress and associated changes in methylation lead to a decrease in transcription of proteins involved in GR signalling and an increase in the expression of transcripts with response elements for NF- $\mathrm{KB}$ governing pro-inflammatory signalling in monocytes [134]. Other research teams have reported very similar findings $[135,136]$. Miller and colleagues reported an increase in monocyte pro-inflammatory activity but reported no changes in GR function or sensitivity, although they also noted a decrease in the transcription of proteins enabling GR function [137]. Changes in gene methylation patterns by chronic GC exposure are well documented (reviewed in [138]), but there is considerable debate regarding the persistence of environmentally induced epigenetic changes over a lifespan (reviewed in [139]). There is also evidence that the methylation status of a GR promoter gene is confounded by adult experiences [140]. In addition, there are a number of prospective studies demonstrating that the association between low economic status and significantly increased susceptibility to immune- or inflammation-mediated diseases is a result of persistent immune dysregulation $[141,142]$. On the other hand, while compromised GR function could certainly play a role, a study of chronic stress in the caregivers of family members suffering from the aggressive brain tumour glioblastoma multiforme did not show any significant change in GR functioning compared with control subjects who were assessed as not having experienced major stressors during the previous year [137]. The question arises however as to how such immune dysregulation provoked by extreme childhood stressors persists into adulthood and why such a universally observed phenomenon leads to the development of pathology in some individuals but not others. We now move on to suggest a mechanism which might underpin this phenomenon based on individual genetic and epigenetic variance.

\section{Factors Involved in Influencing the Duration and Magnitude of an Inflammatory Response}

\section{Genetic Factors}

Several research teams have adduced evidence demonstrating that genetic factors strongly influence the intensity and duration of the immune response and the levels of inflammation produced by the activation of enzyme systems such as mitogen activated protein (MAP) kinases and Janus kinase (JAK)/ STAT [143-147]. The most common source of genetic variation examined in connection to this area is that of functional single nucleotide polymorphisms (SNPs) [145, 146]. For example, in a large study involving 700 participants, Li and colleagues [148] reported a strong impact of genetic hereditability on the levels of cytokine production by PMBCs including monocytes. Pertinently, there is a considerable body of evidence indicating that SNPs in the genes encoding IL-1, IL-6 and TNF- $\alpha$, which are all known to be elevated in people suffering from the effects of SED, influence the performance of the immune system [149-151]. It would also seem worthy of note that the composition of the microbiota also determines the levels of cytokines produced by the activation of immune and inflammatory pathways [152]. This may be relevant as exposure to chronic stressors can provoke dysbiosis and increased gastrointestinal permeability, thus allowing the translocation of commensal antigens into the peripheral circulation and provoking immune activation via the activation of TLRs on macrophages and dendritic cells [153, 154].

The significance of these findings extend to the observation that prolonged or excessive activation of immune and inflammatory pathways can induce tissue damage, leading to the formation of immunogenic DAMPs [35, 36]. These may activate 
TLRs on APCs leading to increased activity and levels of $\mathrm{NF}-\mathrm{KB}$ and further increases in PIC levels. Increased levels of PICs can lead to still further increases in NF- $\mathrm{KB}$ production [155] and increased levels of NF-KB can stimulate the production of yet higher levels of PICs as well as cyclooxygenase-2,5lipoxygenase and inducible nitric oxide synthase (iNOS), thereby driving a cellular environment of chronic oxidative and nitrosative stress (reviewed in $[156,157]$ ). Increasing levels of PICs together with increasing levels of ROS and reactive nitrogen species (RNS) can induce further damage to tissues and macromolecules leading to increased DAMP formation and TLR engagement, ultimately producing higher levels of PICs and free radical species [36]. Increased levels of PICs ROS, RNS and NF- $\mathrm{KB}$ can also combine to drive a self-sustaining cellular environment of chronic inflammation and oxidative stress by modulating epigenetic mechanisms, notably DNA methylation and histone acetylation, responsible for governing the performance of immune and inflammatory pathways during and after activation, as we will now discuss $[158,159]$.

\section{Epigenetic Factors}

\section{Effect of PICs, ROS, RNS and NF-KB on DNA Methylation Levels}

DNA methylation levels of CpG islands (DNA sequences with a high frequency of $\mathrm{CpG}$ sites) in promoter regions regulates the transcription of cytokine-encoding genes either directly or via regulating the activity of transcription factors such as STAT-1, NF-KB and NFAT-1 $[160,161]$. These in turn regulate the production of these inflammatory mediators in response to the activation of numerous cellular stimuli such as the activation of PRRs on APCs by invading pathogens, the presence of DAMPs or increased levels of oxidative stress [161, 162](reviewed in [163]). In general, hypomethylation and increases in the production of these transcription factors result in increased levels of PICs, but the same effect can result from hypermethylation and reduced activity of molecules which inhibit PIC production such as the suppressors of cytokine synthesis (SOCS) [164]. PICs in turn affect the methylation status of genes involved in the regulation of immune and inflammatory activity by the suppression of methyltransferases and methylases which govern levels of gene DNA methylation $[165,166]$. For example, high levels of PICs suppress the activity of DNA methyltransferase 1 (DNMT-1) leading to hypomethylation of the IL-1B promoter and a hundredfold increase in the serum levels of this cytokine [166]. DNA methylation levels also determine the magnitude and duration of immune and inflammatory responses by regulating the activity of macrophages and dendritic cells as well as regulating the activation and differentiation patterns of T cells [167, 168]. This is a brief outline of the interdependency between levels of gene methylation and the activity of immune and inflammatory pathways and readers interested in more details are invited to consult an excellent review by [169]. Increased levels of PIC production, ROS and RNS can cause changes in histone acetylation patterns in promoter regions of genes governing inflammatory signalling, which may also contribute to maintaining, if not amplifying, inflammation and oxidative stress via a positive feedback loop which we will now discuss.

\section{Effects of Increased PICs, ROS, RNS and NF-KB on Histone Acetylation}

Increased levels of inflammation, in the guise of elevated TNF- $\alpha$ and ROS, induce widespread hypomethylation and activation of a wide range of inflammatory transcription factors including NF-KB $[170,171]$. Oxidative stress also induces hyperacetylation of NF- $\mathrm{KB}$ leading to increased DNA binding capacity [32]. Increased levels and transcriptional activity of NF- $\mathrm{kB}$ can induce the expression of co-inflammatory mediators via the activation of intrinsic histone acetyl transferase (HAT) activity and inhibition of histone deacetylases (HDACs) [170]. This is part of the complex effects of NF-KB on chromatin remodelling which drive the expression of genes and other transcription factors involved in regulating a plethora of inflammatory pathways $[172,173]$. The activation of $\mathrm{NF}-\mathrm{KB}$ also results in increased production of PICs and ROS, once again potentially contributing to the development of selfsustaining inflammation and oxidative stress [36].

\section{Effect of PICs, ROS, RNS and NF-KB on miRNA Activity}

miRNAs are small non-coding RNA molecules with roles in post-transcriptional regulation of gene expression and RNA silencing. Several miRNAs are induced by PICs, ROS, RNS and NF-KB [33, 174]. Furthermore, the weight of evidence indicates that the activities of PICs and miRNAs are strongly intertwined, as levels of miRNA expression change in response to stimulation by a range of cytokines, and cytokine gene expression is in turn regulated by changes in the activity of miRNAs and cytokine stimulation [175], while cytokine expression is regulated by miRNAs [176, 177]. Elevated levels of PICs and NF- $\mathrm{KB}$ can induce the production of microRNA-155 (miR-155) in macrophages, monocytes and myeloid dendritic cells $[21,176,178]$. Once activated, miR155 increases the transcription of NF- $\mathrm{KB}$, leading to increased production of PICs [179]. Similarly, NF-KB engages in a positive feedback loop with miR-181b-1 [179]. Briefly, NF-KB activation leads to increased levels of IL-6 which induces the phosphorylation of STAT-3 which transactivates miR-181b-1 which in turn transactivates NF- $\mathrm{KB}$, providing yet another mechanism enabling self-sustaining levels of inflammation and oxidative stress $[180,181]$.

Another pro-inflammatory miRNA which is upregulated by PICs and NF-kB is miR-146a [21, 182, 183]. Unlike the case of miR-181b-1, however, the activation of this miRNA 
species does not lead to the transactivation of NF- $\mathrm{kB}$ but rather acts to inhibit this transcription factor via a somewhat complex negative feedback mechanism [179]. However, the upregulation of miR-146a has profound pro-inflammatory consequences and is involved in the development and propagation of neuroinflammation in illnesses such as MS and AD [184-186]. This miRNA was originally detected following LPS activation of monocytes but its greatest density is found in astrocytes and microglia. It might therefore be involved in the development and maintenance of low-grade neuroinflammation subsequent to the peripheral inflammation driven by prolonged SED and ACE [21, 187]. Given the information above, it seems reasonable to suggest that there are mechanisms which could at least partially explain how the activation of immune and inflammatory pathways in an individual exposed to SED or profound ACE could become chronic. We now move on to consider how genetics and epigenetics, chronic inflammation, as well as nitrosative and oxidative stress, could affect the activity of the HPA axis in childhood after showing that this effect could persist into adulthood.

\section{Factors Involved in Regulating HPA Axis Activity}

\section{Genetic Factors}

In adults, the inflammatory response to socioeconomic and other stressors is determined by genetic and epigenetic factors, with GR polymorphisms and GR methylation status both being involved [188]. GR and MR polymorphisms also play an important role in determining the magnitude and duration of HPA responses to the presence of environmental or internal stressors [189-191]. GR polymorphisms are associated with an increased risk of developing Crohn's disease [192], metabolic syndrome, cardiovascular disease, neurological disease and neuroprogressive illnesses such as MDD [193-195]. Interestingly, GR polymorphisms are predictive of a significantly increased risk of developing post-traumatic stress disorder (PTSD) independently of childhood trauma. Polymorphisms in genes encoding proteins involved in regulating $\mathrm{GC}$ availability, such as the multidrug resistance transporter complex, 11 beta-hydroxysteroid dehydrogenase and corticosteroidbinding globulin, are also associated with an increased risk of developing $\mathrm{AD}$, type 2 diabetes mellitus and a number of other inflammatory illnesses [130, 196-200]. It is also interesting that the performance of each of these proteins can be stimulated by immune activation [199]. At the very least, these data suggest that the levels of inflammation and immune activation experienced by individuals following SED can be significantly influenced by variability in genes regulating the activity of the HPA axis. The situation is rendered even more complex by data revealing that epigenetic factors also regulate the activity of the HPA axis [139] and data discussed above suggesting that an environment of chronic inflammation and oxidative stress leads to dysregulation of DNA methylation, histone acetylation and miRNA production, which could also drive abnormalities in HPA axis function.

\section{Epigenetic Factors}

A growing number of research teams have proposed that methylation of genes involved in the regulation of GR function or expression within the HPA axis might be an important vehicle enabling changes in $\mathrm{GC}$ regulation in response to prolonged SED and/or ACE $[139,201,202]$. Indeed, the association between SED, ACE and NR3C1 or FKBP5 methylation has been established in several recent studies and systematic reviews $[139,201,203,204]$. However, thus far, only the methylation of NR3C1, FKBP5 and HSD11 $\beta 2$ has been examined in direct relation to an increased risk for the development of any human illness, with the vast bulk of research being focused on the methylation status of alternative promoter regions of $\mathrm{NR} 3 \mathrm{Cl}$ $[139,201,202]$. Therefore, the effects of SED or ACE on methylation levels and clinical outcomes of the $P O M C$, $A C T H, A C T H-R, A V P, C R H, C R H-R 1 / 2$ or $C R H-B P$ genes, which are all involved in the regulation of GC levels and activity by the HPA axis, are currently unknown [205]. There is also some doubt regarding the biological importance of the changes in methylation levels reported by the authors listed above. For example, Palma-Gudiel and colleagues reviewed 23 papers investigating methylation changes in the $\mathrm{NR} 3 \mathrm{Cl}$ gene induced by ACE and concluded that the absolute differences in methylation levels are slight, with the majority of authors reporting group differences of less than $5 \%$, which is currently close to the limit of sensitivity of the methylation detection assays utilised [133, 206]. These are important findings as there is a considerable body of evidence indicating that changes in the overall methylation levels of any gene of $10 \%$ may not be biologically relevant $[207,208]$ and changes of $5 \%$ or less should be treated with extreme caution [209].

In addition, it has been suggested that slight changes in gene methylation levels can be the product of failure to stratify results to take account of confounding variables such as age, sex, current SES and cell tissue type [210, 211]. The latter point may be especially relevant as recorded changes in methylation changes may ultimately originate from a small percentage of the cellular population, often described as marginal cellular subsets, leading to insignificant transcriptional changes. This is of interest from the perspective of SED- and/or ACE-induced methylation changes and the ultimate effect on HPA axis functionality as authors have reported a lack of association between methylation of FKBP5 or $\mathrm{NR} 3 \mathrm{Cl}$ and increases in protein levels [212] or changes in GC regulation [213]. In addition, the concept that SED and ACE can induce methylation changes in HPA axis genes in the absence of genetic predisposition is under 
challenge, as several research teams have reported that changes in FKBP5 and NR3Cl methylation in MDD and PTSD patients with a history of SED and or ACE are only seen in people with acknowledged risk genotypes, which does not seem to be the case with SED- and ACE-induced changes in the methylation status of genes involved in the activation and regulation of peripheral immune genes [206, 214-216]. Finally, a review of 32 studies investigating the association between SED and or ACE on HPA axis gene methylation patterns by Argentieri and colleagues concluded that the vast bulk of studies are of crosssectional or case control design and thus incapable of determining whether the methylation changes might be a cause or a product of pathology, which is a significant observation as such changes could be induced by the presence of inflammatory mediators, as discussed above [205]. However, this area is currently the subject of intense research and debate and it would be unwise to reach any firm conclusions based on current data. Readers interested in an in-depth examination of data appertaining to small changes in the methylation of genes and possible changes in the cellular proteosome are invited to consult an excellent review by Leenen and others [213]. For the sake of completeness, it should be noted that the performance of the HPA axis is also regulated by levels of histone acetylation $[217,218]$ and the activity of several miRNAs, such as miR-18 and miR-124 [219, 220], which may be dysregulated following exposure to prolonged stress [220,221]. There is little evidence regarding the persistence of these changes, however, or any evidence of an association with human diseases or any association with a history of SEDs or ACE, and hence, they would not seem to be relevant to this review.

\section{Chronic Inflammation}

There is a large and accumulating body of evidence confirming the rapid downregulation of HPA axis activity in an environment of chronic systemic inflammation [222, 223]. This downregulation is largely mediated by PICs via a number of different mechanisms [224-226]. PICs such as TNF- $\alpha$ and IL-1 $\beta$ can inhibit the activity of $\mathrm{CRH}$-secreting neurones and androgen synthesis in the suprarenal (adrenal) cortex, which may go some way to explaining the low basal levels of cortisol evident in several autoimmune, neurological and neuroprogressive illnesses [227, 228]. High levels of PICs also seem to have the capacity to attenuate stimulatory effects of CRH and ACTH on the suprarenal cortex and pituitary gland (see Fig. 2) [229]. Chronically elevated levels of PICs also appear responsible for HPA axis downregulation as a result of GR dysfunction leading to GC resistance. Cytokines such as TNF- $\alpha$ and IL$1 \beta$ provoke GR dysfunction via several routes such as inhibiting the transcription of GRs and inhibiting their nuclear translocation [230]. There are also data indicating that IL-1 $\beta$ in particular inhibits GR function by activation of the p38/MAPK (MAP kinase) pathway [108].
A range of other enzymes and transcription factors upregulated by PICs such as JAK transcription factors, NFAT, AP-1 and NF-KB have the capacity to inhibit GR function [231, 232]. The mechanisms underpinning such inhibition include dysregulation or disruption of GR translocation to the nucleus, in a similar manner to the effect of PICs, and interference with GR-DNA binding via a series of protein-protein interactions. NF-kB, AP-1, IL-1, TNF- $\alpha$, IL-6 and other inflammatory mediators such as cyclooxygenase (COX) can also disrupt the activity of crucial GR cofactors as well as provoke changes in the phosphorylation status of GRs [101, 233, 234]. Finally, there is also a body of evidence suggesting that chronic exposure to PICs changes the relative abundance of the two GR isoforms, with an increase in the dominant negative beta isoform and a decrease in the alpha isoform leading to a marked decrease in GR efficiency, which may be the major mechanism underpinning GC resistance in chronic inflammatory conditions such as RA [110, 235].

\section{Chronic Nitrosative and Oxidative Stress}

An environment of chronic nitrosative and oxidative stress in the brain disrupts normal HPA axis function via several mechanisms including increased glutamate toxicity and reduced levels of RNA synthesis, RNA stability, mitochondrial function and activity of redox-sensitive kinases. This is a complex area and readers interested in a detailed treatment of this area are invited to consult the work of Spiers and others [236]. GC receptors are also under redox control and elevated concentrations of ROS exert detrimental effects on several aspects of GR function, such as translocation to the nucleus, leading to impaired feedback following HPA axis activation [237] (reviewed in [238]). High levels of nitrosative stress and consequently elevated levels of nitric oxide (NO) lead to a downregulation of GR expression [239, 240].

NO regulates a plethora of interactions between neuroimmune and neuroendocrine systems in physiologically normal and pathological conditions and neuronal nitric oxide synthase (nNOS) acts as a major modulator of processes governing the development of learning [241]. NO is involved in the regulation of corticosterone secretion and nNOS inhibits the activity of GR in the hippocampus resulting in the modulation of HPA axis activity [241, 242]. NO, in tandem with prostaglandins, plays a major role in enabling and regulating the activation of the HPA axis by CRH [243] (reviewed in [244]) and high NO levels exert broadly inhibitory effects [245]. Activation of the HPA axis leads to a profound inflammatory response and a significant increase in NO levels as well as increased levels of PICs and prostanoids [241] .

The downstream effects of NO and PICs are different however, and while CRH release, and consequent stimulation of ACTH secretion from the anterior pituitary, involves the synthesis and release of IL-1, IL- 6 and TNF- $\alpha$, NO released in the 


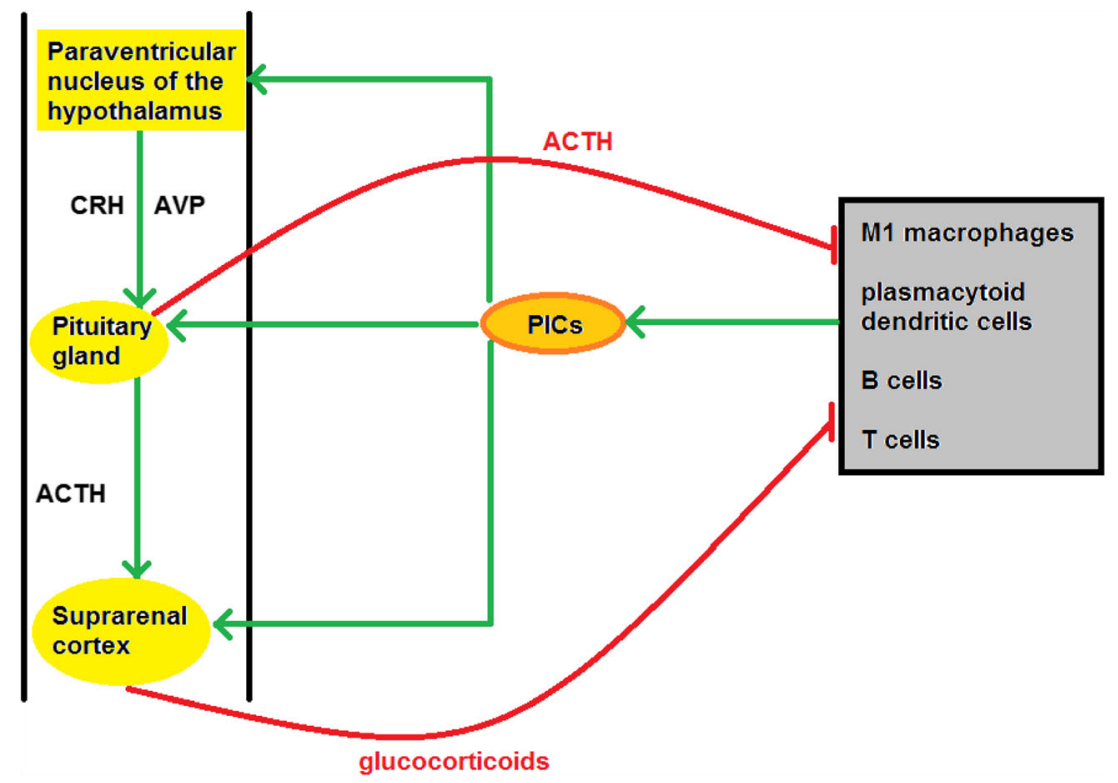

Fig. 2 Bidirectional communication between the immune and neuroendocrine systems. PICs released by PMBCs can activate the HPA axis at the level of the pituitary, the paraventricular nucleus of the hypothalamus and the suprarenal (adrenal) cortex, stimulating the synthesis and secretion of GCs. The latter act on the surface or cytoplasmic receptors of PMBCs to suppress the transcription and

translation of pro-inflammatory "Th1" cytokines such as IL-1 and IL-6 and increase the production of anti-inflammatory "Th2" cytokines such as IL-4 and IL-10, thus promoting a downwards shift in the immune response. ACTH release also exerts an independent direct immunosuppressive effect mediated via the melanocortin system

PVN modulates signal transduction pathways governing corticosterone release from the suprarenal (adrenal) gland [241]. NO also engages in "crosstalk" with GRs [246] and can upregulate these receptors to produce broadly anti-inflammatory effects [247]. However, at higher levels, NO inhibits GR binding [248, 249], offering another mechanism by which elevated nitrosative and oxidative stress compromises the antiinflammatory capability of the HPA axis. In this context, it is noteworthy that loss of GR activity can produce aberrant GRNO crosstalk leading to loss of neuroprotective functions conferred by astroglia in response to immune activation in the periphery [246]. There would appear to be ample evidence demonstrating that chronically upregulated levels of PICs, ROS and RNS can provoke dysfunction of the HPA axis. However, there is also evidence that stress-upregulated PICs, ROS and RNS in the periphery and the brain experienced during childhood can induce persistent and potentially pathological consequences in adulthood other than via detrimental effects on the neuroendocrine system, and we now turn to consideration of the evidence in this domain.

\section{Other Putative Pathological Consequences of Elevated PICs, RNS and ROS}

\section{ACE and the Development of Oxidative Stress}

Authors investigating the effects of social adversity in rodents have reported neuropathological consequences induced in part by increased levels of ROS and RNS coupled with reduced enzymatic and non-enzymatic anti-oxidants in the periphery and in areas of the brain such as the hippocampus forebrain striatum and cortex. Individual findings include reduced levels of superoxide dismutase (SOD) and catalase and widespread disruption of the glutathione (GSH) system such as a reduced GSH/GSSG ratio and depleted levels of glutathione peroxidase (GPx) [250-252]. These results are mirrored in human studies such as those examining the relationship between the extreme adverse social experiences during wartime relating to the development of neuropathology such as PTSD in general and Gulf War syndrome in particular, as we now go on to describe.

Once again, accumulating data indicate that increased brain oxidative stress stemming from war experiences is an important factor [253]. For example, excessive increases in cerebrospinal fluid (CSF) and CNS levels of $\mathrm{NO}$ /peroxynitrite is a reproducible finding in Gulf War veterans, whether or not such individuals suffered from PTSD, and appear to correlate with the extent of structural changes in the brain [253]. In addition, PTSD observed in American soldiers returning from Iraq has been associated with ROS-mediated brain changes [254]. In Gulf War veterans affected by PTSD, elevation in the levels of 8-hydroxy-2'-deoxyguanosine (8-OHdG) and the induction of 3-nitrotyrosine in the CSF have been reported; 8$\mathrm{OHdG}$ is a biomarker of oxidative DNA damage [255]. Some research teams have also reported a putative association between the prolonged psychological stress of divorce and the development of significantly increased oxidative stress in the 
brains and periphery of adults and children [256]. This profile also appears to be dominated by a denuded cellular antioxidant system and thus reduced resistance to the corrosive effects of ROS and RNS [257].

The association between childhood sexual abuse and the development of persistent oxidative stress and inflammation is difficult to assess despite the existence of a plethora of studies investigating the subject. Some authors have reported an increase in both parameters in the short term but not in the long term while other authors have reported no difference compared with age- and sex-matched children with no history of such experiences [258, 259] (reviewed in [260]). The relationship between childhood maltreatment and the development of persistent oxidative stress appears to be much clearer however despite the difficulties in consistently defining the term [259, 261-263]. For example, do Prado and others reported that childhood maltreatment was associated with oxidative stress as shown by increased protein carbonylation, higher SOD levels and reduced GPx levels when compared with adolescents who had not undergone childhood maltreatment [261]. Very similar results have been reported in a more recent study by Morares and others who reported that various dimensions of childhood maltreatment such as physical abuse or neglect are associated with increased oxidative and nitrosative stress evidenced by the presence of lipid peroxidation, protein carbonylation and abnormalities in cellular enzymatic and nonenzymatic antioxidant levels [259]. These results have also been replicated by the same team of authors in an even more recent study [263]. In the latter instance, this research group also reported that the extent of lipid peroxidation and depleted antioxidant systems was predictive of the development and the severity of affective disorders which developed in later life [263].

The study conducted by Boeck and others is also of particular interest as these authors reported that childhood maltreatment was associated with increased oxidative stress as a result of increased mitochondrial ROS production secondary to increased activity in these organelles. Moreover, these authors also noted that such an elevation of ROS production and mitochondrial activity correlated positively with the release of PICs by PMBCs and depleted serum levels of lysophosphatidylcholines highly suggestive of increased levels of inflammasome activation [262].

\section{Oxidative Stress and the Development of Generalised Neuropathology}

There is evidence to suggest that the source of oxidative stress seen in the brains of children and adults exposed to extreme and/or protracted life stress is activated NADPH oxidase (NOX) isoforms, most notably NOX-2 [264, 265]. This is perhaps unsurprising as NOX is upregulated in activated microglia and is the primary source of ROS production by these glial cells in this state [266,267]. Once activated, NOX plays a major role in maintaining microglial activation and influences microglial polarisation towards the neurotoxic M1 phenotype [268].

The relationship between activated or ramified microglia and upregulated NOX-induced ROS production is of interest as severe or protracted psychological stress and the development of persistent peripheral inflammation known to activate microglia would go some way to explaining the relationship between severe life experiences and oxidative stress in the brain as discussed above [37, 111, 269, 270] (reviewed in [271]). It should be noted that stress-induced elevation of GCs in the brain increases microglial activation, priming and the development of a pro-inflammatory phenotype independently of the existence of peripheral inflammation [38-40]. Chronic and/or protracted stress also leads to "primed" microglia, which is a state which renders these cells exquisitely sensitive to further activation by even trivial peripheral stimuli such as minor infections or minor social stressors [272, 273]. This inherent sensitivity makes individuals more susceptible to the detrimental effects of "life experiences" and hence microglial priming could potentially provide a vehicle for conveying the effects of early-life stressors to adulthood and increases the chances of developing the neuropathology associated with neuropsychiatric and neurological conditions [274].

Early-life stressors may have a more direct effect on the later development of neuropathology, however, as the weight of evidence suggests that severe or protracted psychological stress may disrupt the normal bidirectional signalling between microglia, astrocytes and neurones with potentially devastating effects on brain function and brain development [275] (reviewed in [276]). Severe stress also has a direct and detrimental effect on levels of GABA, dopamine, serotonin, noradrenaline (norepinephrine) and glutamate neurotransmitters and various structures involved in neurotransmission mediated by each of these molecules, which could also play a role in communicating the effects of childhood psychological stress into adulthood (reviewed in [277]). For example, increased microglial ROS production mediates the development of glutamate toxicity, leading to mitochondrial damage and NMDA receptor upregulation, leading to further increases in ROS and the development of self-amplifying pathology [278, 279].

In addition, animal and human studies have demonstrated that psychological stress also increases glutamate levels and excitotoxicity in various regions of the brain including the prefrontal cortex, hippocampus and amygdala [280] (reviewed in [281]). Several research teams have reported that such changes in glutamatergic neurotransmission are induced directly by elevated GC levels [282, 283]. Activation of microglia and astrocytes via the existence of peripheral inflammation or increased levels of CNS GRs also has a detrimental effect of glutamatergic neurotransmission, as resting 
astrocytes play an indispensable role in glutamate uptake and the receptors that enable this activity are significantly downregulated or even absent on the membranes of these glial cells in the activated state [38-40,111, 156]. Chronic glutamate upregulation also increases the expression of type 1 metabotropic glutamate receptors [284]. This is also of pathological relevance as upregulation and engagement of these receptors in the VPN inhibits the HPA axis stress response [285].

Finally, there is accumulating evidence from animal studies that genetic and epigenetic variation in the components of various neurotransmitter systems may go some distance to explaining the phenomenon of resilience (reviewed in [286]). For example, genetic variability in GABA receptors is associated with increased susceptibility or resilience to the effects of short term psychological stress while differences in the epigenetic regulation of serotonin receptors produces very similar consequences [287, 288]. This is clearly not the main focus of this paper and readers interested in the area are referred to an excellent and very recent review by Schiele and Domschke [289]. We now turn to the final section of the paper which examines mitochondrial dysfunction as vehicle for conveying multisystem dysregulation caused by ACE into adulthood.

\section{Mitochondria as Couriers of Childhood Stress into Adulthood}

\section{ACE and the Development of Mitochondrial Dysfunction}

A recent meta-analysis of 23 studies concluded that protracted and/or severe psychological stress is associated with profound and detrimental changes in mitochondrial performance, structural integrity, morphology and dynamics in the periphery and in the brain [290]. The most commonly reported indices of impaired mitochondrial function and respiration appear to be decreased complex I and IV activity, impaired complex I directed respiration, decreased membrane potential and increased permeability transition pore sensitivity [291-293]. Several research teams have also reported evidence of ultrastructural damage and altered morphology with increased lipid peroxidation, organelle swelling, loss of cristae and reduced matrix density [294, 295]. Psychological stress is also associated with reduced mitochondrial DNA (mtDNA) copy number in the rodent brain and changes in mtDNA transcription. For example, Liu and Zhou reported a $60 \%$ reduction in mtDNA copy number in corticosterone-treated rats in the hippocampus and striatum, with a slightly lower reduction in rats subjected to chronic unpredictable mild stress, while Roosevelt and others reported decreased transcription of mtDNA sequences coding for proteins involved in the structure of complex I of the electron transport chain (ETC) [291,
296]. Other authors have reported that psychosocial stress adversely influences global mitochondrial gene transcription $[297,298]$. It is also noteworthy that there is some evidence that genetic variation in mtDNA may influence the susceptibility of mitochondria to the effects of psychological stress [299]. In addition, the use of metabolomics has revealed significant changes in the production and secretion of mitochondrial metabolites in the brain and blood of animals in a state of stress compared with unstressed controls [300, 301]. Furthermore, several authors utilising proteomic technology have reported strikingly similar results with significant changes in the protein composition of mitochondria during stressed versus unstressed conditions [302, 303]. The mechanisms whereby psychosocial stress exerts such a plethora of pathological effects on mitochondrial performance and physiology are the subject of intense research and may in part result from oxidative damage to mtDNA which is known to induce transcriptional abnormalities and organelle dysfunction [304, 305].

\section{Consequences of Mitochondrial Dysfunction}

This is of prime importance as the weight of evidence suggests that variations in mtDNA sequences and/or expression influence the neuroendocrine, metabolic, inflammatory and transcriptional response to stress [15]. Moreover, mitochondrial dysfunction evidenced by dysregulated mtDNA expression or otherwise can have detrimental effects on the autonomic nervous system and the HPA axis as well as increasing levels of inflammation, lipids and glucose, which in total are regarded as being the main contributors to increased allostatic load and allostatic overload, which is predictive, at least to some extent, of the development of pathology as discussed above [14, 306] (reviewed in [16]).

The mechanisms whereby mitochondrial dysfunction can have detrimental effects on other harbingers of allostatic load are well documented and straightforward. For example, allostasis is an energy requiring process and environmental stressors provoke a significant increase in energy generation (reviewed in [290]). Similarly, mitochondrial dysfunction in adipocytes and insulin responsive tissues is a major, if not the main, driver of systemically elevated lipids and hyperglycaemia via well-established pathways (reviewed in [24, 25]). However, the mechanisms whereby mitochondrial dysfunction can have detrimental effects on the HPA axis and the neuroendocrine and transcriptional responses to stress appear to be under-discussed and hence are worthy of further consideration.

Epigenetic regulation of gene transcription, which plays a vital role in enabling allostasis as discussed above, is dependent on metabolites derived from the tricarboxylic acid cycle or produced elsewhere within mitochondria (reviewed in [23]). Importantly, this dependence relates to the addition 
and removal of epigenetic modifications. For example, cytoplasmic acetyl coenzyme A, derived from citrate exported from mitochondria, is an indispensable substrate enabling histone acetylation [307], and thus, at least a basal level of mitochondrial metabolism is needed to enable optimum histone acetylation [308]. Histone and DNA demethylation also depend on physiological levels of the citric acid cycle intermediate $\alpha$-ketoglutarate and hence this process also requires optimum mitochondrial metabolism [309]. The precise relationship between compromised mitochondrial function and impaired genetic machinery is not fully understood but there is some evidence to suggest that it is facilitated by retrograde mitochondria to nucleus signalling [310], which also probably provides the vehicle whereby mitochondrial metabolism influences or regulates the expression of more than $50 \%$ of human genes [311].

Mitochondria are also the site of synthesis for GCs and all other steroid hormones and hence mitochondrial dysfunction could lead to significantly reduced GR production leading to a denuded anti-inflammatory response and impaired HPA axis feedback [312] (reviewed in [313]). GRs can also influence mitochondrial function following translocation into the organelles, probably via binding with GC response elements on mtDNA [314, 315]. Crucially, the weight of evidence suggests that chronic and/or excessive GR exposure during severe or protracted psychological stress dysregulates mitochondrial $\mathrm{Ca}^{2+}$ homeostasis, decreases mitochondrial respiration, damages enzymes of the ETC, reduces membrane potential and increases mitochondrial ROS production [316-318]. The actions of other stress hormones, notably the catecholamines noradrenaline and adrenaline (epinephrine), can also have detrimental effects on mitochondrial function and integrity in the periphery and the brain by inducing deletions in mtDNA [319, 320]. Finally, and perhaps predictably, there are accumulating data suggesting that the other effector molecule of the autonomic nervous system response to stress, namely acetylcholine, can also induce significant damage to mitochondria in all body compartments via engagement with the nAChRs on the outer membranes of these organelles [321]. Such engagement appears to disturb mitochondrial calcium homeostasis by

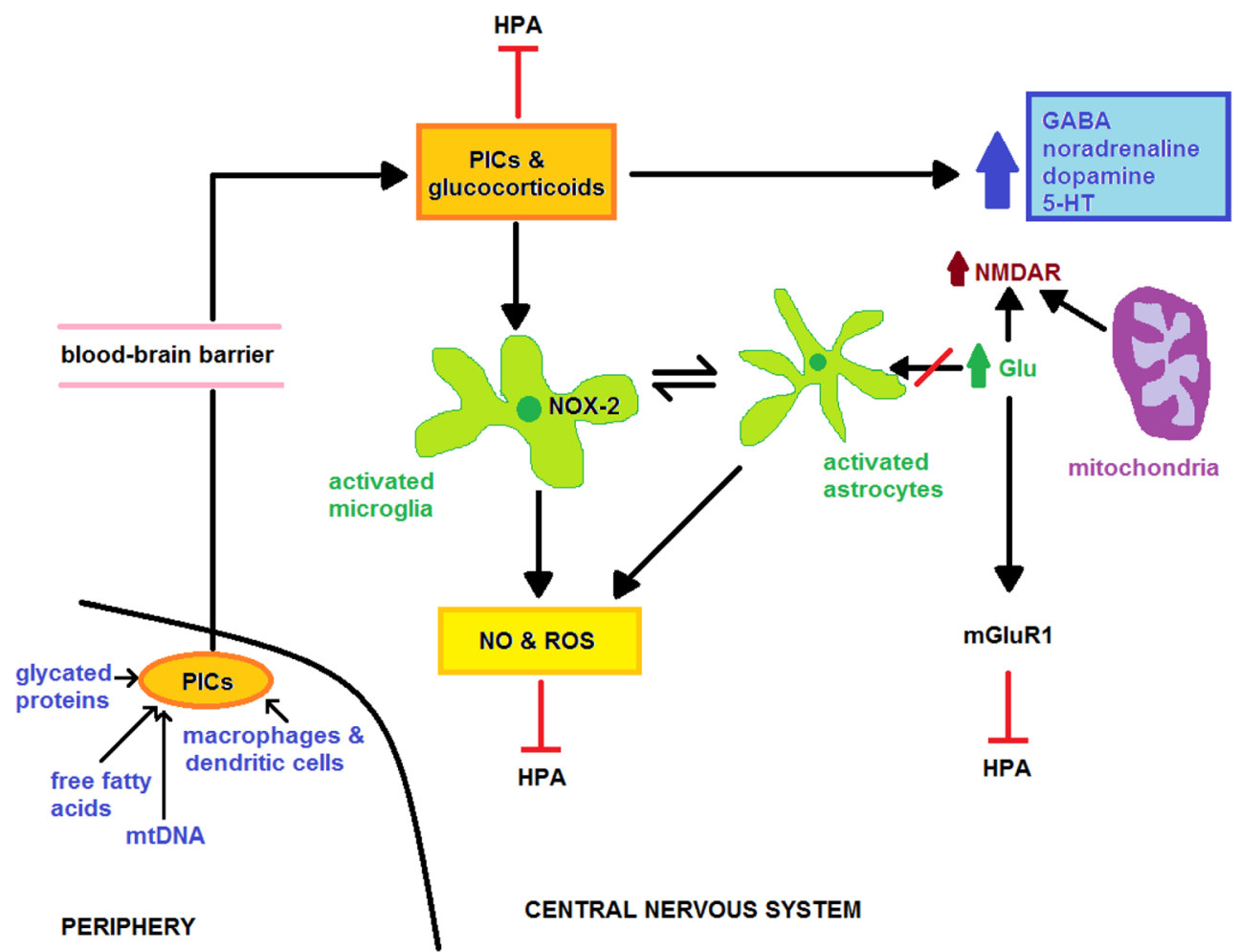

Fig. 3 In this model, persistent peripheral inflammation caused by prolonged psychosocial stress in the guise of elevated PICs is transmitted to the brain via a number of well documented routes which then acts alone or in tandem with raised GCs to activate microglia and astrocytes. Their activation exerts a plethora of neurotoxic consequences such as the release of ROS, RNS and PICs and failure of astrocytic glutamate reuptake mechanisms, leading to glutamate excitotoxicity, increased activity of type 1 metabotropic glutamate receptors and NMDA receptor dysfunction. The ROS, RNS and PICs secreted by activated glial cells can also induce widespread dysregulation in
GABAergic, serotoninergic, noradrenergic and dopaminergic neurotransmission as well as inhibiting the HPA axis via several mechanisms. Microglia and astrocytes may also be activated by elevated CNS GCs and prolonged or severe psychosocial stress in the absence of peripheral inflammation; elevations of these molecules can independently produce the same detrimental effects on glutamate excitotoxicity, NMDA dysfunction and other neurotransmitter systems as glial cell-derived ROS RNS and PICs. The development and persistence of peripheral and central inflammation are influenced by genetic and epigenetic factors (see text) 
inhibiting voltage-dependent anion channel (VDAC)-regulated $\mathrm{Ca}^{2+}$ uptake from the cytoplasm, opening the permeability transition pore resulting in the release of cytochrome $c$ and activation of the PI3K/Akt signalling pathway [321, 322]. The sum of these effects can result in a potentially catastrophic fall in adenosine triphosphate production and, in the extreme, cell death via apoptosis or necrosis, with the latter having significant pro-inflammatory consequences [321, 322] (reviewed in [323]).

This is of importance as research teams have reported that under conditions of psychological stress damaged or dysfunctional mitochondria can release mtDNA and other mitochondrial DAMPs into the cytoplasm and circulation, leading to the development of systemic inflammation, immune activation and inhibition of the HPA axis [324, 325]. The mechanisms involved stem from the fact that mtDNA is a potent DAMP (also known as mitochondrial alarmin), owing to its close resemblance to bacterial DNA, and hence is able to activate AIM2 (absent in melanoma 2), NLRP3 (NOD (nucleotide-binding oligomerisation domain), leucine-rich repeats and pyrin domain-containing protein 3 ) inflammasomes and TLR-9 and provoke a type 1 interferon response [326] reviewed in [327]. Moreover, the presence of mtDNA in the systemic circulation can contribute to the development of systemic oxidative stress and further exacerbate systemic inflammation via the activation of NF-KB and the subsequent increase in levels of ROS, RNS and PICs [328, 329]. There is also evidence to suggest that the inflammation and oxidative stress invoked by mtDNA can inflict further damage on mitochondria leading to a feedforward loop of increasing inflammation and oxidative stress [326]. Such a scenario has the potential to cause oxidative and peroxidative damage to proteins and lipids and to provoke conformational changes which can also render these molecules immunogenic and capable of activating PRRs, thereby providing another route for selfamplifying inflammation and oxidative stress $[35,36]$. It should also be noted that increased systemic levels of saturated fatty acids and hyperglycaemia, which can both result from mitochondrial dysfunction, can also potentially make an independent contribution to the development of systemic inflammation and oxidative stress $[27,28,330]$. Mechanistically, this is achieved via the activation of TLR-4 by free fatty acids [27, 331] and RAGE (receptor(s) for advanced glycation end products) by glycated proteins [28, 332]. It is also noteworthy that systemic inflammation either induced by "escaped" mtDNA or otherwise is known to activate microglia and hence could also account for data demonstrating increased levels of oxidative stress in the brain of animals and individuals exposed to severe psychosocial stress $[37,111]$. In addition, it would seem that the sensitivity of microglia to developing a primed phenotype is dependent on genetic and epigenetic mechanisms [333]. The mechanisms discussed above are represented in Fig. 3.

\section{Conclusion}

We have shown that there is strong evidence that childhood SED and/or ACE is associated with the development of adult HPA axis dysfunction and neuropsychiatric, neurodegenerative and autoimmune illnesses. Important contributors to the allostatic load experience during childhood include mitochondrial dysfunction, nitrosative and oxidative stress and inflammation, which in turn affect the regulation of HPA axis activity, including via epigenetic factors. We have also seen how PICs, RNS and ROS can have other pathological, including neuropathological, consequences and how mitochondria can act as couriers of childhood stress into adulthood. The latter is of importance as changes in mtDNA sequences and/or expression can influence the endocrine, metabolic, inflammatory and transcriptional response to stress. These findings provide pointers to future research and to potential therapeutic interventions.

Authorships All authors contributed to the writing up of the paper. GM and BP produced the figures.

\section{Compliance with Ethical Standards}

Conflict of Interest The authors declare that they have no competing interests.

Open Access This article is distributed under the terms of the Creative Commons Attribution 4.0 International License (http:// creativecommons.org/licenses/by/4.0/), which permits unrestricted use, distribution, and reproduction in any medium, provided you give appropriate credit to the original author(s) and the source, provide a link to the Creative Commons license, and indicate if changes were made.

Publisher's Note Springer Nature remains neutral with regard to jurisdictional claims in published maps and institutional affiliations.

\section{References}

1. Bick J, Naumova O, Hunter S, Barbot B, Lee M, Luthar SS, Raefski A, Grigorenko EL (2012) Childhood adversity and DNA methylation of genes involved in the hypothalamuspituitary-adrenal axis and immune system: whole-genome and candidate-gene associations. Dev Psychopathol 24(4):14171425. https://doi.org/10.1017/s0954579412000806

2. Castagne R, Delpierre C, Kelly-Irving M, Campanella G, Guida F, Krogh V, Palli D, Panico S et al (2016) A life course approach to explore the biological embedding of socioeconomic position and social mobility through circulating inflammatory markers. Sci Rep 6:25170. https://doi.org/10.1038/srep25170

3. Franz CE, Spoon K, Thompson W, Hauger RL, Hellhammer DH, Jacobson KC, Lupien S, Lyons MJ et al (2013) Adult cognitive ability and socioeconomic status as mediators of the effects of childhood disadvantage on salivary cortisol in aging adults. Psychoneuroendocrinology 38(10):2127-2139. https://doi.org/ 10.1016/j.psyneuen.2013.04.001 
4. Kohler CA, Freitas TH, Maes M, de Andrade NQ, Liu CS, Fernandes BS, Stubbs B, Solmi M et al (2017) Peripheral cytokine and chemokine alterations in depression: a meta-analysis of 82 studies. Acta Psychiatr Scand 135(5):373-387. https://doi.org/ 10.1111/acps. 12698

5. Morris G, Berk M (2015) The many roads to mitochondrial dysfunction in neuroimmune and neuropsychiatric disorders. BMC Med 13(1):68

6. Morris G, Berk M, Galecki P, Walder K, Maes M (2015) The Neuro-immune pathophysiology of central and peripheral fatigue in systemic immune-inflammatory and neuro-immune diseases. Mol Neurobiol 53(2):1195-1219. https://doi.org/10.1007/ s12035-015-9090-9

7. Bellavance M-A, Rivest S (2014) The HPA-immune axis and the immunomodulatory actions of glucocorticoids in the brain. Front Immunol 5. https://doi.org/10.3389/fimmu.2014.00136

8. Panagiotakos DB, Pitsavos C, Manios Y, Polychronopoulos E, Chrysohoou CA, Stefanadis C (2005) Socio-economic status in relation to risk factors associated with cardiovascular disease, in healthy individuals from the ATTICA study. Eur J Cardiovasc Prev Rehabil 12(1):68-74

9. Hemingway H, Shipley M, Mullen MJ, Kumari M, Brunner E, Taylor M, Donald AE, Deanfield JE et al (2003) Social and psychosocial influences on inflammatory markers and vascular function in civil servants (the Whitehall II Study). Am J Cardiol 92(8): 984-987

10. Hartwell KJ, Moran-Santa Maria MM, Twal WO, Shaftman S, DeSantis SM, McRae-Clark AL, Brady KT (2013) Association of elevated cytokines with childhood adversity in a sample of healthy adults. J Psychiatr Res 47(5):604-610. https://doi.org/10. 1016/j.jpsychires.2013.01.008

11. Beutel ME, Tibubos AN, Klein EM, Schmutzer G, Reiner I, Kocalevent RD, Brahler E (2017) Childhood adversities and distress - the role of resilience in a representative sample. PLoS One 12(3):e0173826. https://doi.org/10.1371/journal.pone. 0173826

12. Ben-David V, Jonson-Reid M (2017) Resilience among adult survivors of childhood neglect: a missing piece in the resilience literature. Child Youth Serv Rev 78:93-103. https://doi.org/10.1016/j. childyouth.2017.05.014

13. McEwen BS (2017) Allostasis and the epigenetics of brain and body health over the life course: the brain on stress. JAMA Psychiatry 74(6):551-552. https://doi.org/10.1001/ jamapsychiatry.2017.0270

14. Wiley JF, Gruenewald TL, Karlamangla AS, Seeman TE (2016) Modeling multisystem physiological dysregulation. Psychosom Med 78(3):290-301. https://doi.org/10.1097/psy. 0000000000000288

15. Picard M, McManus MJ, Gray JD, Nasca C, Moffat C, Kopinski PK, Seifert EL, McEwen BS et al (2015) Mitochondrial functions modulate neuroendocrine, metabolic, inflammatory, and transcriptional responses to acute psychological stress. Proc Natl Acad Sci U S A 112(48):E6614-E6623. https://doi.org/10.1073/pnas. 1515733112

16. Goldstein DS (2011) Stress, allostatic load, catecholamines, and other neurotransmitters in neurodegenerative diseases. Endocr Regul 45(2):91-98

17. Medvedev AE (2013) Toll-Like receptor polymorphisms, inflammatory and infectious diseases, allergies, and cancer. J Interf Cytokine Res 33(9):467-484. https://doi.org/10.1089/jir.2012. 0140

18. Lin Y-T, Verma A, Hodgkinson CP (2012) Toll-like receptors and human disease: lessons from single nucleotide polymorphisms. Curr Genomics 13(8):633-645. https://doi.org/10.2174/ 138920212803759712
19. Vandenbroeck K (2012) Cytokine gene polymorphisms and human autoimmune disease in the era of genome-wide association studies. J Interf Cytokine Res 32(4):139-151. https://doi.org/10. 1089/jir.2011.0103

20. Richard AC, Peters JE, Lee JC, Vahedi G, Schaffer AA, Siegel RM, Lyons PA, Smith KG (2016) Targeted genomic analysis reveals widespread autoimmune disease association with regulatory variants in the TNF superfamily cytokine signalling network. Genome Med 8(1):76. https://doi.org/10.1186/s13073-016-0329-

21. Hill JM, Clement C, Zhao Y, Lukiw WJ (2015) Induction of the pro-inflammatory NF-kB-sensitive miRNA-146a by human neurotrophic viruses. Front Microbiol 6:43. https://doi.org/10.3389/ fmicb.2015.00043

22. Cuperfain AB, Zhang ZL, Kennedy JL, Gonçalves VF (2018) The complex interaction of mitochondrial genetics and mitochondrial pathways in psychiatric disease. Mol Neuropsychiatry 4(1):52-69. https://doi.org/10.1159/000488031

23. Matilainen O, Quiros PM, Auwerx J (2017) Mitochondria and epigenetics - crosstalk in homeostasis and stress. Trends Cell Biol 27(6):453-463. https://doi.org/10.1016/j.tcb.2017.02.004

24. de Mello AH, Costa AB, Engel JDG, Rezin GT (2018) Mitochondrial dysfunction in obesity. Life Sci 192:26-32. https://doi.org/10.1016/j.lfs.2017.11.019

25. Montgomery MK, Turner N (2015) Mitochondrial dysfunction and insulin resistance: an update. Endocr Connect 4(1):R1-R15. https://doi.org/10.1530/EC-14-0092

26. Picard M, McEwen BS, Epel ES, Sandi C (2018) An energetic view of stress: focus on mitochondria. Front Neuroendocrinol 49: 72-85. https://doi.org/10.1016/j.yfrne.2018.01.001

27. Rocha DM, Caldas AP, Oliveira LL, Bressan J, Hermsdorff HH (2016) Saturated fatty acids trigger TLR4-mediated inflammatory response. Atherosclerosis 244:211-215. https://doi.org/10.1016/j. atherosclerosis.2015.11.015

28. Ramasamy R, Yan SF, Schmidt AM (2011) Receptor for AGE (RAGE): signaling mechanisms in the pathogenesis of diabetes and its complications. Ann N Y Acad Sci 1243:88-102. https:// doi.org/10.1111/j.1749-6632.2011.06320.x

29. Murgatroyd C (2014) Epigenetic programming of neuroendocrine systems during early life. Exp Physiol 99(1):62-65. https://doi. org/10.1113/expphysiol.2013.076141

30. Morris G, Anderson G, Maes M (2017) Hypothalamic-pituitaryadrenal hypofunction in myalgic encephalomyelitis (ME)/chronic fatigue syndrome (CFS) as a consequence of activated immuneinflammatory and oxidative and nitrosative pathwayS. Mol Neurobiol 54(9):6806-6819. https://doi.org/10.1007/s12035016-0170-2

31. Miller GE, Chen E, Fok AK, Walker H, Lim A, Nicholls EF, Cole S, Kobor MS (2009) Low early-life social class leaves a biological residue manifested by decreased glucocorticoid and increased proinflammatory signaling. Proc Natl Acad Sci U S A 106(34): 14716-14721. https://doi.org/10.1073/pnas.0902971106

32. Gu X, Sun J, Li S, Wu X, Li L (2013) Oxidative stress induces DNA demethylation and histone acetylation in SH-SY5Y cells: potential epigenetic mechanisms in gene transcription in Abeta production. Neurobiol Aging 34(4):1069-1079. https://doi.org/ 10.1016/j.neurobiolaging.2012.10.013

33. Chen Z, Shentu T-P, Wen L, Johnson DA, Shyy JYJ (2013) Regulation of SIRT1 by oxidative stress-responsive miRNAs and a systematic approach to identify its role in the endothelium. Antioxid Redox Signal 19(13):1522-1538. https://doi.org/10. 1089/ars.2012.4803

34. Morris G, Maes M, Murdjeva M, Puri BK (2018) Do human endogenous retroviruses contribute to multiple sclerosis, and if so, how? Mol Neurobiol. https://doi.org/10.1007/s12035-018$1255-\mathrm{x}$ 
35. Lucas K, Maes M (2013) Role of the Toll like receptor (TLR) radical cycle in chronic inflammation: possible treatments targeting the TLR4 pathway. Mol Neurobiol 48:190-204

36. Lucas K, Morris G, Anderson G, Maes M (2015) The Toll-like receptor radical cycle pathway: a new drug target in immunerelated chronic fatigue. CNS Neurol Disord Drug Targets 14(7): $838-854$

37. Morris G, Anderson G, Galecki P, Berk M, Maes M (2013) A narrative review on the similarities and dissimilarities between myalgic encephalomyelitis/chronic fatigue syndrome (ME/CFS) and sickness behavior. BMC Med 11:64

38. Nair A, Bonneau RH (2006) Stress-induced elevation of glucocorticoids increases microglia proliferation through NMDA receptor activation. J Neuroimmunol 171(1):72-85. https://doi.org/10. 1016/j.jneuroim.2005.09.012

39. Frank MG, Thompson BM, Watkins LR, Maier SF (2012) Glucocorticoids mediate stress-induced priming of microglial pro-inflammatory responses. Brain Behav Immun 26(2):337345. https://doi.org/10.1016/j.bbi.2011.10.005

40. Park M-J, Yeo H-L, You M-J, Kim B, Kwon M-S (2016) PS206. Persistent glucocorticoid receptor activation reduces M2-like microglia phenotypes without inflammatory signaling. Int $\mathrm{J}$ Neuropsychopharmacol 19(Suppl_1):75. https://doi.org/10.1093/ ijnp/pyw043.206

41. Witzmann SR, Turner JD, Mériaux SB, Meijer OC, Muller CP (2012) Epigenetic regulation of the glucocorticoid receptor promoter 1(7) in adult rats. Epigenetics 7(11):1290-1301. https://doi. org/10.4161/epi.22363

42. Shonkoff JP (2011) Protecting brains, not simply stimulating minds. Science 333(6045):982-983. https://doi.org/10.1126/ science. 1206014

43. Shonkoff JP, Boyce WT, McEwen BS (2009) Neuroscience, molecular biology, and the childhood roots of health disparities: building a new framework for health promotion and disease prevention. JAMA 301(21):2252-2259. https://doi.org/10.1001/ jama.2009.754

44. O'Neil A, Jacka FN, Quirk SE, Cocker F, Taylor CB, Oldenburg B, Berk M (2015) A shared framework for the common mental disorders and non-communicable disease: key considerations for disease prevention and control. BMC Psychiatry 15:15. https:// doi.org/10.1186/s12888-015-0394-0

45. Anda RF, Brown DW, Dube SR, Bremner JD, Felitti VJ, Giles WH (2008) Adverse childhood experiences and chronic obstructive pulmonary disease in adults. Am J Prev Med 34(5):396-403. https://doi.org/10.1016/j.amepre.2008.02.002

46. Dube SR, Fairweather D, Pearson WS, Felitti VJ, Anda RF, Croft JB (2009) Cumulative childhood stress and autoimmune diseases in adults. Psychosom Med 71(2):243-250. https://doi.org/10. 1097/psy.0b013e3181907888

47. Gluckman PD, Hanson MA, Cooper C, Thornburg KL (2008) Effect of in utero and early-life conditions on adult health and disease. N Engl J Med 359(1):61-73. https://doi.org/10.1056/ NEJMra0708473

48. Goodwin RD, Stein MB (2004) Association between childhood trauma and physical disorders among adults in the United States. Psychol Med 34(3):509-520

49. Matthews KA, Chang Y, Bromberger JT, Karvonen-Gutierrez CA, Kravitz HM, Thurston RC, Montez JK (2016) Childhood socioeconomic circumstances, inflammation, and hemostasis among midlife women: study of women's health across the nation. Psychosom Med 78(3):311-318. https://doi.org/10.1097/psy. 0000000000000283

50. Rich-Edwards JW, Spiegelman D, Lividoti Hibert EN, Jun HJ, Todd TJ, Kawachi I, Wright RJ (2010) Abuse in childhood and adolescence as a predictor of type 2 diabetes in adult women. Am J
Prev Med 39(6):529-536. https://doi.org/10.1016/j.amepre.2010. 09.007

51. Riley EH, Wright RJ, Jun HJ, Hibert EN, Rich-Edwards JW (2010) Hypertension in adult survivors of child abuse: observations from the Nurses' Health Study II. J Epidemiol Community Health 64(5):413-418. https://doi.org/10.1136/jech.2009.095109

52. Keinan-Boker L, Vin-Raviv N, Liphshitz I, Linn S, Barchana M (2009) Cancer incidence in Israeli Jewish survivors of World War II. J Natl Cancer Inst 101(21):1489-1500. https://doi.org/10.1093/ jnci/djp327

53. Kittleson MM, Meoni LA, Wang NY, Chu AY, Ford DE, Klag MJ (2006) Association of childhood socioeconomic status with subsequent coronary heart disease in physicians. Arch Intern Med 166(21):2356-2361. https://doi.org/10.1001/archinte.166.21. 2356

54. Slopen N, Kubzansky LD, McLaughlin KA, Koenen KC (2013) Childhood adversity and inflammatory processes in youth: a prospective study. Psychoneuroendocrinology 38(2):188-200. https://doi.org/10.1016/j.psyneuen.2012.05.013

55. Chen E, Hanson MD, Paterson LQ, Griffin MJ, Walker HA, Miller GE (2006) Socioeconomic status and inflammatory processes in childhood asthma: the role of psychological stress. J Allergy Clin Immunol 117(5):1014-1020. https://doi.org/10. 1016/j.jaci.2006.01.036

56. Chen E, Fisher EB, Bacharier LB, Strunk RC (2003) Socioeconomic status, stress, and immune markers in adolescents with asthma. Psychosom Med 65(6):984-992

57. Fraga S, Marques-Vidal P, Vollenweider P, Waeber G, Guessous I, Paccaud F, Barros H, Stringhini S (2015) Association of socioeconomic status with inflammatory markers: a two cohort comparison. Prev Med 71:12-19. https://doi.org/10.1016/j.ypmed.2014. 11.031

58. Loucks EB, Sullivan LM, Hayes LJ, D'Agostino RB, Larson MG, Vasan RS, Benjamin EJ, Berkman LF (2006) Association of educational level with inflammatory markers in the framingham offspring study. Am J Epidemiol 163(7):622-628. https://doi.org/10. 1093/aje/kwj076

59. Jousilahti P, Salomaa V, Rasi V, Vahtera E, Palosuo T (2003) Association of markers of systemic inflammation, $\mathrm{C}$ reactive protein, serum amyloid A, and fibrinogen, with socioeconomic status. J Epidemiol Community Health 57(9):730-733

60. Ranjit N, Diez-Roux AV, Shea S, Cushman M, Ni H, Seeman T (2007) Socioeconomic position, race/ethnicity, and inflammation in the multi-ethnic study of atherosclerosis. Circulation 116(21): 2383-2390. https://doi.org/10.1161/circulationaha.107.706226

61. Gruenewald TL, Cohen S, Matthews KA, Tracy R (1982) Seeman TE (2009) Association of socioeconomic status with inflammation markers in black and white men and women in the Coronary Artery Risk Development in Young Adults (CARDIA) study. Soc Sci Med 69(3):451-459. https://doi.org/10.1016/j. socscimed.2009.05.018

62. Steinvil A, Shirom A, Melamed S, Toker S, Justo D, Saar N, Shapira I, Berliner S et al (2008) Relation of educational level to inflammation-sensitive biomarker level. Am J Cardiol 102(8): 1034-1039. https://doi.org/10.1016/j.amjcard.2008.05.055

63. Danese A, Pariante CM, Caspi A, Taylor A, Poulton R (2007) Childhood maltreatment predicts adult inflammation in a lifecourse study. Proc Natl Acad Sci U S A 104(4):1319-1324. https://doi.org/10.1073/pnas.0610362104

64. Pollitt RA, Kaufman JS, Rose KM, Diez-Roux AV, Zeng D, Heiss G (2007) Early-life and adult socioeconomic status and inflammatory risk markers in adulthood. Eur J Epidemiol 22(1):55-66. https://doi.org/10.1007/s10654-006-9082-1

65. Koster A, Bosma H, Penninx BW, Newman AB, Harris TB, van Eijk JT, Kempen GI, Simonsick EM et al (2006) Association of 
inflammatory markers with socioeconomic status. J Gerontol A Biol Sci Med Sci 61(3):284-290

66. Carroll JE, Cohen S, Marsland AL (2011) Early childhood socioeconomic status is associated with circulating interleukin-6 among mid-life adults. Brain Behav Immun 25(7):1468-1474. https://doi. org/10.1016/j.bbi.2011.05.016

67. Pace TW, Mletzko TC, Alagbe O, Musselman DL, Nemeroff CB, Miller AH, Heim CM (2006) Increased stress-induced inflammatory responses in male patients with major depression and increased early life stress. Am J Psychiatry 163(9):1630-1633. https://doi.org/10.1176/ajp.2006.163.9.1630

68. Loucks EB, Pilote L, Lynch JW, Richard H, Almeida ND, Benjamin EJ, Murabito JM (2010) Life course socioeconomic position is associated with inflammatory markers: the Framingham Offspring Study. Soc Sci Med (1982) 71(1):187195. https://doi.org/10.1016/j.socscimed.2010.03.012

69. Stringhini S, Batty GD, Bovet P, Shipley MJ, Marmot MG, Kumari M, Tabak AG, Kivimaki M (2013) Association of lifecourse socioeconomic status with chronic inflammation and type 2 diabetes risk: the Whitehall II prospective cohort study. PLoS Med 10(7):e1001479. https://doi.org/10.1371/journal. pmed.1001479

70. Kelly-Irving M, Mabile L, Grosclaude P, Lang T, Delpierre C (2013) The embodiment of adverse childhood experiences and cancer development: potential biological mechanisms and pathways across the life course. Int J Public Health 58(1):3-11. https:// doi.org/10.1007/s00038-012-0370-0

71. Ben-Shlomo Y, Kuh D (2002) A life course approach to chronic disease epidemiology: conceptual models, empirical challenges and interdisciplinary perspectives. Int J Epidemiol 31(2):285-293

72. Beydoun MA, Wang Y (2010) Pathways linking socioeconomic status to obesity through depression and lifestyle factors among young US adults. J Affect Disord 123(1-3):52-63. https://doi.org/ 10.1016/j.jad.2009.09.021

73. Montez JK, Bromberger JT, Harlow SD, Kravitz HM, Matthews KA (2016) Life-course socioeconomic status and metabolic syndrome among midlife women. J Gerontol Ser B Psychol Sci Soc Sci 71(6):1097-1107. https://doi.org/10.1093/geronb/gbw014

74. McClure CK, El Khoudary SR, Karvonen-Gutierrez CA, Ylitalo KR, Tomey K, VoPham T, Sternfeld B, Cauley JA et al (2014) Prospective associations between inflammatory and hemostatic markers and physical functioning limitations in mid-life women: longitudinal results of the Study of Women's Health Across the Nation (SWAN). Exp Gerontol 49:19-25. https://doi.org/10.1016/ j.exger.2013.10.016

75. Camelo LV, Giatti L, Neves JA, Lotufo PA, Bensenor IM, Chor D, Griep RH, da Fonseca MJ et al (2014) Life course socioeconomic position and C-reactive protein: mediating role of health-risk behaviors and metabolic alterations. The Brazilian Longitudinal Study of Adult Health (ELSA-Brasil). PLoS One 9(10):e108426. https://doi.org/10.1371/journal.pone.0108426

76. Lawrence GM, Siscovick DS, Calderon-Margalit R, Enquobahrie DA, Granot-Hershkovitz E, Harlap S, Manor O, Meiner V et al (2016) Cohort profile: the Jerusalem Perinatal Family Follow-Up Study. Int J Epidemiol 45(2):343-352. https://doi.org/10.1093/ije/ dyv120

77. Baumeister D, Akhtar R, Ciufolini S, Pariante CM, Mondelli V (2016) Childhood trauma and adulthood inflammation: a metaanalysis of peripheral C-reactive protein, interleukin-6 and tumour necrosis factor-[alpha]. Mol Psychiatry 21(5):642-649. https:// doi.org/10.1038/mp.2015.67

78. Chen E, Cohen S, Miller GE (2010) How low socioeconomic status affects 2-year hormonal trajectories in children. Psychol Sci 21(1):31-37. https://doi.org/10.1177/0956797609355566
79. Evans GW, Kim P (2007) Childhood poverty and health: cumulative risk exposure and stress dysregulation. Psychol Sci 18(11): 953-957. https://doi.org/10.1111/j.1467-9280.2007.02008.x

80. Gustafsson PE, Anckarsater H, Lichtenstein P, Nelson N, Gustafsson PA (2010) Does quantity have a quality all its own? Cumulative adversity and up- and down-regulation of circadian salivary cortisol levels in healthy children. Psychoneuroendocrinology 35(9):1410-1415. https://doi.org/10. 1016/j.psyneuen.2010.04.004

81. Hunter AL, Minnis H, Wilson P (2011) Altered stress responses in children exposed to early adversity: a systematic review of salivary cortisol studies. Stress (Amsterdam, Netherlands) 14(6):614 626. https://doi.org/10.3109/10253890.2011.577848

82. Dowd JB, Simanek AM, Aiello AE (2009) Socio-economic status, cortisol and allostatic load: a review of the literature. Int $\mathrm{J}$ Epidemiol 38(5):1297-1309. https://doi.org/10.1093/ije/dyp277

83. Rippe RC, Noppe G, Windhorst DA, Tiemeier H, van Rossum EF, Jaddoe VW, Verhulst FC, Bakermans-Kranenburg MJ et al (2016) Splitting hair for cortisol? Associations of socio-economic status, ethnicity, hair color, gender and other child characteristics with hair cortisol and cortisone. Psychoneuroendocrinology 66:5664. https://doi.org/10.1016/j.psyneuen.2015.12.016

84. Serwinski B, Salavecz G, Kirschbaum C, Steptoe A (2016) Associations between hair cortisol concentration, income, income dynamics and status incongruity in healthy middle-aged women. Psychoneuroendocrinology 67:182-188. https://doi.org/10.1016/ j.psyneuen.2016.02.008

85. Vaghri Z, Guhn M, Weinberg J, Grunau RE, Yu W, Hertzman C (2013) Hair cortisol reflects socio-economic factors and hair zinc in preschoolers. Psychoneuroendocrinology 38(3):331-340. https://doi.org/10.1016/j.psyneuen.2012.06.009

86. Wosu AC, Valdimarsdóttir U, Shields AE, Williams DR, Williams MA (2013) Correlates of cortisol in human hair: implications for epidemiologic studies on health effects of chronic stress. Ann Epidemiol 23(12):797-811.e792. https://doi.org/10.1016/j. annepidem.2013.09.006

87. Chikanza IC (2002) Mechanisms of corticosteroid resistance in rheumatoid arthritis: a putative role for the corticosteroid receptor beta isoform. Ann N Y Acad Sci 966:39-48

88. Eijsbouts AM, Murphy EP (1999) The role of the hypothalamicpituitary-adrenal axis in rheumatoid arthritis. Baillieres Best Pract Res Clin Rheumatol 13(4):599-613. https://doi.org/10.1053/berh. 1999.0048

89. Cash JM, Crofford LJ, Gallucci WT, Sternberg EM, Gold PW, Chrousos GP, Wilder RL (1992) Pituitary-adrenal axis responsiveness to ovine corticotropin releasing hormone in patients with rheumatoid arthritis treated with low dose prednisone. J Rheumatol 19(11):1692-1696

90. Johnson EO, Kostandi M, Moutsopoulos HM (2006) Hypothalamicpituitary-adrenal axis function in Sjogren's syndrome: mechanisms of neuroendocrine and immune system homeostasis. Ann N Y Acad Sci 1088(1):41-51. https://doi.org/10.1196/annals.1366.018

91. Tzioufas AG, Tsonis J, Moutsopoulos HM (2008) Neuroendocrine dysfunction in Sjogren's syndrome. Neuroimmunomodulation 15(1): 37-45. https://doi.org/10.1159/000135622

92. Demitrack MA, Dale JK, Straus SE, Laue L, Listwak SJ, Kruesi MJ, Chrousos GP, Gold PW (1991) Evidence for impaired activation of the hypothalamic-pituitary-adrenal axis in patients with chronic fatigue syndrome. J Clin Endocrinol Metab:73. https:// doi.org/10.1210/jcem-73-6-1224

93. Braga J, Campar A (2014) Biological causes of depression in systemic lupus erythematosus. Acta Reumatol Port 39(3):218-226

94. Mok C, Lau C (2003) Pathogenesis of systemic lupus erythematosus. J Clin Pathol 56:481-490

95. Wei T, Lightman SL (1997) The neuroendocrine axis in patients with multiple sclerosis. Brain 120(Pt 6):1067-1076 
96. Melief J, de Wit SJ, van Eden CG, Teunissen C, Hamann J, Uitdehaag BM, Swaab D, Huitinga I (2013) HPA axis activity in multiple sclerosis correlates with disease severity, lesion type and gene expression in normal-appearing white matter. Acta Neuropathol 126(2):237-249. https://doi.org/10.1007/s00401013-1140-7

97. Marques-Deak AH, Neto FL, Dominguez WV, Solis AC, Kurcgant D, Sato F, Ross JM, Prado EBA (2007) Cytokine profiles in women with different subtypes of major depressive disorder. J Psychiatr Res 41(1):152-159. https://doi.org/10.1016/j. jpsychires.2005.11.003

98. Generaal E, Vogelzangs N, Macfarlane GJ, Geenen R, Smit JH, Penninx BW, Dekker J (2014) Reduced hypothalamic-pituitaryadrenal axis activity in chronic multi-site musculoskeletal pain: partly masked by depressive and anxiety disorders. BMC Musculoskelet Disord 15(1):1-11. https://doi.org/10.1186/14712474-15-227

99. Powell DJH, Liossi C, Moss-Morris R, Schlotz W (2013) Unstimulated cortisol secretory activity in everyday life and its relationship with fatigue and chronic fatigue syndrome: a systematic review and subset meta-analysis. Psychoneuroendocrinology 38(11):2405-2422. https://doi.org/10.1016/j.psyneuen.2013.07. 004

100. Minkel J, Moreta M, Muto J, Htaik O, Jones C, Basner M, Dinges D (2014) Sleep deprivation potentiates HPA axis stress reactivity in healthy adults. Health Psychol 33(11):1430-1434. https://doi. org/10.1037/a0034219

101. Pace TW, Hu F, Miller AH (2007) Cytokine-effects on glucocorticoid receptor function: relevance to glucocorticoid resistance and the pathophysiology and treatment of major depression. Brain Behav Immun 21(1):9-19. https://doi.org/10.1016/j.bbi.2006.08. 009

102. Kamimura D, Yamada M, Harada M, Sabharwal L, Jie M, Bando $\mathrm{H}$, Ogura H, Atsumi T et al (2013) The gateway theory: bridging neural and immune interactions in the CNS. Front Neurosci 7. https://doi.org/10.3389/fnins.2013.00204

103. ThyagaRajan S, Priyanka HP (2012) Bidirectional communication between the neuroendocrine system and the immune system: relevance to health and diseases. Ann Neurosci 19(1):40-46. https:// doi.org/10.5214/ans.0972.7531.180410

104. Procaccini C, Pucino V, De Rosa V, Marone G, Matarese G (2014) Neuro-endocrine networks controlling immune system in health and disease. Front Immunol 5:143. https://doi.org/10.3389/fimmu. 2014.00143

105. Engler KL, Rudd ML, Ryan JJ, Stewart JK, Fischer-Stenger K (2005) Autocrine actions of macrophage-derived catecholamines on interleukin-1 beta. J Neuroimmunol 160(1-2):87-91. https:// doi.org/10.1016/j.jneuroim.2004.11.005

106. Taub DD (2008) Neuroendocrine interactions in the immune system. Cell Immunol 252(1-2):1-6. https://doi.org/10.1016/j. cellimm.2008.05.006

107. Rosas-Ballina M, Olofsson PS, Ochani M, Valdes-Ferrer SI, Levine YA, Reardon C, Tusche MW, Pavlov VA et al (2011) Acetylcholine-synthesizing T cells relay neural signals in a vagus nerve circuit. Science 334(6052):98-101. https://doi.org/10.1126/ science. 1209985

108. Wang X, Wu H, Miller AH (2004) Interleukin 1alpha (IL-1alpha) induced activation of $\mathrm{p} 38$ mitogen-activated protein kinase inhibits glucocorticoid receptor function. Mol Psychiatry 9(1):6575. https://doi.org/10.1038/sj.mp.4001339

109. Wang H, Yu M, Ochani M, Amella CA, Tanovic M, Susarla S, Li JH, Wang $\mathrm{H}$ et al (2003) Nicotinic acetylcholine receptor alpha7 subunit is an essential regulator of inflammation. Nature 421(6921):384-388. https://doi.org/10.1038/nature01339

110. Webster JC, Oakley RH, Jewell CM, Cidlowski JA (2001) Proinflammatory cytokines regulate human glucocorticoid receptor gene expression and lead to the accumulation of the dominant negative $\beta$ isoform: a mechanism for the generation of glucocorticoid resistance. Proc Natl Acad Sci 98(12):6865-6870. https://doi.org/10.1073/pnas.121455098

111. Morris G, Berk M, Walder K, Maes M (2015) Central pathways causing fatigue in neuro-inflammatory and autoimmune illnesses. BMC Med 13(1):28

112. Seruga B, Zhang H, Bernstein LJ, Tannock IF (2008) Cytokines and their relationship to the symptoms and outcome of cancer. Nat Rev Cancer 8(11):887-899

113. Johnston GR, Webster NR (2009) Cytokines and the immunomodulatory function of the vagus nerve. Br J Anaesth. https:// doi.org/10.1093/bja/aep037

114. Goehler LE, Gaykema RP, Hansen MK, Anderson K, Maier SF, Watkins LR (2000) Vagal immune-to-brain communication: a visceral chemosensory pathway. Auton Neurosci 85(1-3):49-59. https://doi.org/10.1016/s1566-0702(00)00219-8

115. Ulrich-Lai YM, Herman JP (2009) Neural regulation of endocrine and autonomic stress responses. Nat Rev Neurosci 10(6):397-409. https://doi.org/10.1038/nrn2647

116. Lowry CA (2002) Functional subsets of serotonergic neurones: implications for control of the hypothalamic-pituitary-adrenal axis. J Neuroendocrinol 14(11):911-923

117. Stern JE (2015) Neuroendocrine-autonomic integration in the paraventricular nucleus: novel roles for dendritically released neuropeptides. J Neuroendocrinol 27(6):487-497. https://doi.org/10. 1111 /jne. 12252

118. Turrin NP, Rivest S (2006) Molecular and cellular immune mediators of neuroprotection. Mol Neurobiol 34(3):221-242. https:// doi.org/10.1385/mn:34:3:221

119. Howell MP, Muglia LJ (2006) Effects of genetically altered brain glucocorticoid receptor action on behavior and adrenal axis regulation in mice. Front Neuroendocrinol 27(3):275-284. https://doi. org/10.1016/j.yfrne.2006.05.001

120. Vandevyver S, Dejager L, Libert C (2012) On the trail of the glucocorticoid receptor: into the nucleus and back. Traffic (Copenhagen, Denmark) 13(3):364-374. https://doi.org/10.1111/ j.1600-0854.2011.01288.x

121. Echeverria PC, Mazaira G, Erlejman A, Gomez-Sanchez C, Piwien Pilipuk G, Galigniana MD (2009) Nuclear import of the glucocorticoid receptor-hsp90 complex through the nuclear pore complex is mediated by its interaction with Nup62 and importin beta. Mol Cell Biol 29(17):4788-4797. https://doi.org/10.1128/ mcb.00649-09

122. Busillo JM, Azzam KM, Cidlowski JA (2011) Glucocorticoids sensitize the innate immune system through regulation of the NLRP3 inflammasome. J Biol Chem 286(44):38703-38713. https://doi.org/10.1074/jbc.M111.275370

123. Tracey KJ (2009) Reflex control of immunity. Nat Rev Immunol 9(6):418-428. https://doi.org/10.1038/nri2566

124. Laryea G, Muglia L, Arnett M, Muglia LJ (2015) Dissection of glucocorticoid receptor-mediated inhibition of the hypothalamicpituitary-adrenal axis by gene targeting in mice. Front Neuroendocrinol:150-164. https://doi.org/10.1016/j.yfrne.2014. 09.002

125. Rhen T, Cidlowski JA (2005) Antiinflammatory action of glucocorticoids - new mechanisms for old drugs. N Engl J Med 353(16):1711-1723. https://doi.org/10.1056/NEJMra050541

126. Kassel O, Herrlich P (2007) Crosstalk between the glucocorticoid receptor and other transcription factors: molecular aspects. Mol Cell Endocrinol 275(1-2):13-29. https://doi.org/10.1016/j.mce. 2007.07.003

127. Liberman AC, Druker J, Perone MJ, Arzt E (2007) Glucocorticoids in the regulation of transcription factors that control cytokine synthesis. Cytokine Growth Factor Rev 18(1-2):4556. https://doi.org/10.1016/j.cytogfr.2007.01.005 
128. Revollo JR, Cidlowski JA (2009) Mechanisms generating diversity in glucocorticoid receptor signaling. Ann N Y Acad Sci 1179: 167-178. https://doi.org/10.1111/j.1749-6632.2009.04986.x

129. Tait AS, Butts CL, Sternberg EM (2008) The role of glucocorticoids and progestins in inflammatory, autoimmune, and infectious disease. J Leukoc Biol 84(4):924-931. https://doi.org/10.1189/jlb. 0208104

130. Silverman MN, Sternberg EM (2008) Neuroendocrine-immune interactions in rheumatoid arthritis: mechanisms of glucocorticoid resistance. Neuroimmunomodulation 15(1):19-28. https://doi.org/ $10.1159 / 000135620$

131. Lam LL, Emberly E, Fraser HB, Neumann SM, Chen E, Miller GE, Kobor MS (2012) Factors underlying variable DNA methylation in a human community cohort. Proc Natl Acad Sci U S A 109(Suppl 2):17253-17260. https://doi.org/10.1073/pnas. 1121249109

132. Miller GE, Chen E (2010) Harsh family climate in early life presages the emergence of a proinflammatory phenotype in adolescence. Psychol Sci 21(6):848-856. https://doi.org/10.1177/ 0956797610370161

133. Palma-Gudiel H, Cordova-Palomera A, Leza JC, Fananas L (2015) Glucocorticoid receptor gene (NR3C1) methylation processes as mediators of early adversity in stress-related disorders causality: a critical review. Neurosci Biobehav Rev 55:520-535. https://doi.org/10.1016/j.neubiorev.2015.05.016

134. Miller GE, Chen E, Sze J, Marin T, Arevalo JM, Doll R, Ma R, Cole SW (2008) A functional genomic fingerprint of chronic stress in humans: blunted glucocorticoid and increased NFkappaB signaling. Biol Psychiatry 64(4):266-272. https://doi. org/10.1016/j.biopsych.2008.03.017

135. Schwaiger M, Grinberg M, Moser D, Zang JC, Heinrichs M, Hengstler JG, Rahnenfuhrer J, Cole S et al (2016) Altered stressinduced regulation of genes in monocytes in adults with a history of childhood adversity. Neuropsychopharmacology 41(10):2530 2540. https://doi.org/10.1038/npp.2016.57

136. Levine ME, Cole SW, Weir DR, Crimmins EM (2015) Childhood and later life stressors and increased inflammatory gene expression at older ages. Soc Sci Med (1982) 130:16-22. https://doi.org/10. 1016/j.socscimed.2015.01.030

137. Miller GE, Murphy ML, Cashman R, Ma R, Ma J, Arevalo JM, Kobor MS, Cole SW (2014) Greater inflammatory activity and blunted glucocorticoid signaling in monocytes of chronically stressed caregivers. Brain Behav Immun 41:191-199. https://doi. org/10.1016/j.bbi.2014.05.016

138. Bose R, Spulber S, Kilian P, Heldring N, Lonnerberg P, Johnsson A, Conti M, Hermanson O et al (2015) Tet3 mediates stable glucocorticoid-induced alterations in DNA methylation and Dnmt3a/Dkk1 expression in neural progenitors. Cell Death Dis 6:e1793. https://doi.org/10.1038/cddis.2015.159

139. Daskalakis NP, Yehuda R (2014) Site-specific methylation changes in the glucocorticoid receptor exon $1 \mathrm{~F}$ promoter in relation to life adversity: systematic review of contributing factors. Front Neurosci 8:369. https://doi.org/10.3389/fnins.2014.00369

140. de Rooij SR, Costello PM, Veenendaal MV, Lillycrop KA, Gluckman PD, Hanson MA, Painter RC, Roseboom TJ (2012) Associations between DNA methylation of a glucocorticoid receptor promoter and acute stress responses in a large healthy adult population are largely explained by lifestyle and educational differences. Psychoneuroendocrinology 37(6):782-788. https://doi. org/10.1016/j.psyneuen.2011.09.010

141. Fagundes CP, Glaser R, Kiecolt-Glaser JK (2013) Stressful early life experiences and immune dysregulation across the lifespan. Brain Behav Immun 27(1):8-12. https://doi.org/10.1016/j.bbi. 2012.06.014

142. Slopen N, Loucks EB, Appleton AA, Kawachi I, Kubzansky LD, Non AL, Buka S, Gilman SE (2015) Early origins of inflammation: an examination of prenatal and childhood social adversity in a prospective cohort study. Psychoneuroendocrinology 51:403-413. https://doi.org/10.1016/ j.psyneuen.2014.10.016

143. Roederer M, Quaye L, Mangino M, Beddall Margaret H, Mahnke Y, Chattopadhyay P, Tosi I, Napolitano L et al (2015) The genetic architecture of the human immune system: a bioresource for autoimmunity and disease pathogenesis. Cell 161(2):387-403. https:// doi.org/10.1016/j.cell.2015.02.046

144. Orrù V, Steri M, Sole G, Sidore C, Virdis F, Dei M, Lai S, Zoledziewska $\mathrm{M}$ et al (2013) Genetic variants regulating immune cell levels in health and disease. Cell 155(1):242-256. https://doi. org/10.1016/j.cell.2013.08.041

145. Stein CM, Guwatudde D, Nakakeeto M, Peters P, Elston RC, Tiwari HK, Mugerwa R, Whalen CC (2003) Heritability analysis of cytokines as intermediate phenotypes of tuberculosis. J Infect Dis 187(11):1679-1685. https://doi.org/10.1086/375249

146. Newport MJ, Goetghebuer T, Weiss HA, Whittle H, Siegrist CA, Marchant A (2004) Genetic regulation of immune responses to vaccines in early life. Genes Immun 5(2):122-129

147. Ferguson LR, Han DY, Fraser AG, Huebner C, Lam WJ, Morgan AR, Duan H, Karunasinghe N (2010) Genetic factors in chronic inflammation: single nucleotide polymorphisms in the STAT-JAK pathway, susceptibility to DNA damage and Crohn's disease in a New Zealand population. Mutat Res 690(1-2):108-115. https:// doi.org/10.1016/j.mrfmmm.2010.01.017

148. Li Y, Oosting M, Smeekens SP, Jaeger M, Aguirre-Gamboa R, Le KT, Deelen P, Ricano-Ponce I et al (2016) A functional genomics approach to understand variation in cytokine production in humans. Cell 167(4):1099-1110.e1014. https://doi.org/10.1016/j. cell.2016.10.017

149. Obada M, El-Fert A, Hashim MS, Obada M, Ehsan N, Alhadad O, El-Said H (2017) Impact of genetic polymorphisms of four cytokine genes on treatment induced viral clearance in HCV infected Egyptian patients. Egypt J Med Human Genet 18(2):111-119. https://doi.org/10.1016/j.ejmhg.2016.04.002

150. Banerjee M, Saxena M (2014) Genetic polymorphisms of cytokine genes in type 2 diabetes mellitus. World J Diabetes 5(4):493504. https://doi.org/10.4239/wjd.v5.i4.493

151. Dutra WO, Moreira PR, Souza PEA, Gollob KJ, Gomez RS (2009) Implications of cytokine gene polymorphisms on the orchestration of the immune response: lessons learned from oral diseases. Cytokine Growth Factor Rev 20(3):223-232. https:// doi.org/10.1016/j.cytogfr.2009.05.005

152. Schirmer M, Smeekens SP, Vlamakis H, Jaeger M, Oosting M, Franzosa EA, Jansen T, Jacobs L et al (2016) Linking the human gut microbiome to inflammatory cytokine production capacity. Cell 167(4):1125-1136.e1128. https://doi.org/10.1016/j.cell. 2016.10.020

153. Morris G, Maes M (2012) Increased nuclear factor-kappaB and loss of p53 are key mechanisms in myalgic encephalomyelitis/ chronic fatigue syndrome (ME/CFS). Med Hypotheses 79:607613

154. Morris G, Berk M, Carvalho AF, Caso JR, Sanz Y, Maes M (2016) The role of microbiota and intestinal permeability in the pathophysiology of autoimmune and neuroimmune processes with an emphasis on inflammatory bowel disease type 1 diabetes and chronic fatigue syndrome. Curr Pharm Des 22(40):6058-6075

155. Noort AR, Tak PP, Tas SW (2015) Non-canonical NF-kappaB signaling in rheumatoid arthritis: Dr Jekyll and Mr Hyde? Arthritis Res Ther 17:15. https://doi.org/10.1186/s13075-0150527-3

156. Morris G, Maes M (2014) Oxidative and nitrosative stress and immune-inflammatory pathways in patients with myalgic encephalomyelitis (ME)/chronic fatigue syndrome (CFS). Curr 
Neuropharmacol 12(2):168-185. https://doi.org/10.2174/ $1570159 x 11666131120224653$

157. Shih R-H, Wang C-Y, Yang C-M (2015) NF-kappaB signaling pathways in neurological inflammation: a mini review. Front Mol Neurosci 8(77). https://doi.org/10.3389/fnmol.2015.00077

158. Dahmer MK, Cornell T, Quasney MW (2016) Genetic and epigenetic factors in the regulation of the immune response. Curr Opin Pediatr 28(3):281-286. https://doi.org/10.1097/mop. 0000000000000356

159. Hennessy C, McKernan DP (2016) Epigenetics and innate immunity: the 'unTolld' story. Immunol Cell Biol 94(7):631-639. https://doi.org/10.1038/icb.2016.24

160. Provencal N, Suderman MJ, Caramaschi D, Wang D, Hallett M, Vitaro F, Tremblay RE, Szyf M (2013) Differential DNA methylation regions in cytokine and transcription factor genomic loci associate with childhood physical aggression. PLoS One 8(8): e71691. https://doi.org/10.1371/journal.pone.0071691

161. Borghol N, Suderman M, McArdle W, Racine A, Hallett M, Pembrey M, Hertzman C, Power C et al (2012) Associations with early-life socio-economic position in adult DNA methylation. Int J Epidemiol 41(1):62-74. https://doi.org/10.1093/ije/dyr147

162. Li J, Chen F, Zheng M, Zhu H, Zhao D, Liu W, Liu W, Chen Z (2010) Inhibition of STAT1 methylation is involved in the resistance of hepatitis B virus to Interferon alpha. Antivir Res 85(3): 463-469. https://doi.org/10.1016/j.antiviral.2009.10.011

163. Yasmin R, Siraj S, Hassan A, Khan AR, Abbasi R, Ahmad N (2015) Epigenetic regulation of inflammatory cytokines and associated genes in human malignancies. Mediat Inflamm 2015:8. https://doi.org/10.1155/2015/201703

164. Cheng C, Huang C, Ma T-T, Bian E-B, He Y, Zhang L, Li J (2014) SOCS1 hypermethylation mediated by DNMT1 is associated with lipopolysaccharide-induced inflammatory cytokines in macrophages. Toxicol Lett 225(3):488-497. https://doi.org/10.1016/j. toxlet.2013.12.023

165. Winfield J, Esbitt A, Seutter SF, Desai B, Abdo M, Vasconez M, Laidlaw W, Green K et al (2016) Effect of inflammatory cytokines on dna methylation and demethylation. FASEB J 30(1 Supplement): 1053.1053

166. Hashimoto K, Oreffo ROC, Gibson MB, Goldring MB, Roach HI (2009) DNA de-methylation at specific CpG sites in the IL1B promoter in response to inflammatory cytokines in human articular chondrocytes. Arthritis Rheum 60(11):3303-3313. https://doi. org/10.1002/art.24882

167. Wang X, Cao Q, Yu L, Shi H, Xue B, Shi H (2016) Epigenetic regulation of macrophage polarization and inflammation by DNA methylation in obesity. JCI Insight 1(19):e87748. https://doi.org/ 10.1172/jci.insight. 87748

168. Vento-Tormo R, Company C, Rodríguez-Ubreva J, de la Rica L, Urquiza JM, Javierre BM, Sabarinathan R, Luque A et al (2016) IL-4 orchestrates STAT6-mediated DNA demethylation leading to dendritic cell differentiation. Genome Biol 17(1):4. https://doi.org/ 10.1186/s13059-015-0863-2

169. Ligthart S, Marzi C, Aslibekyan S, Mendelson MM, Conneely KN, Tanaka T, Colicino E, Waite LL et al (2016) DNA methylation signatures of chronic low-grade inflammation are associated with complex diseases. Genome Biol 17(1):255. https://doi.org/ 10.1186/s13059-016-1119-5

170. Rahman I, Marwick J, Kirkham P (2004) Redox modulation of chromatin remodeling: impact on histone acetylation and deacetylation, NF-kappaB and pro-inflammatory gene expression. Biochem Pharmacol 68(6):1255-1267. https://doi.org/10.1016/j. bcp.2004.05.042

171. Rahman I, Gilmour PS, Jimenez LA, MacNee W (2002) Oxidative stress and TNF-alpha induce histone acetylation and NF-kappaB/AP-1 activation in alveolar epithelial cells: potential mechanism in gene transcription in lung inflammation. Mol Cell Biochem 234-235(1-2):239-248

172. Xu JW, Ling S, Liu J (2017) Higher-order chromatin regulation of inflammatory gene expression. Mediat Inflamm 2017:7848591. https://doi.org/10.1155/2017/7848591

173. Bhatt D, Ghosh S (2014) Regulation of the NF-kappaB-mediated transcription of inflammatory genes. Front Immunol 5:71. https:// doi.org/10.3389/fimmu.2014.00071

174. Ibrahim AF, Weirauch U, Thomas M, Grunweller A, Hartmann RK, Aigner A (2011) MicroRNA replacement therapy for miR145 and miR-33a is efficacious in a model of colon carcinoma. Cancer Res 71(15):5214-5224. https://doi.org/10.1158/00085472.can-10-4645

175. Lee KS, Kim J, Kwak SN, Lee KS, Lee DK, Ha KS, Won MH, Jeoung D et al (2014) Functional role of NF-kappaB in expression of human endothelial nitric oxide synthase. Biochem Biophys Res Commun 448(1):101-107. https://doi.org/10.1016/j.bbrc.2014. 04.079

176. Ando Y, Yang GX, Kenny TP, Kawata K, Zhang W, Huang W, Leung PS, Lian ZX et al (2013) Overexpression of microRNA-21 is associated with elevated pro-inflammatory cytokines in dominant-negative TGF-beta receptor type II mouse. J Autoimmun 41:111-119. https://doi.org/10.1016/j. jaut.2012.12.013

177. Kim JS, Yu SK, Lee MH, Park MG, Park E, Kim SG, Lee SY, Kim CS et al (2013) MicroRNA-205 directly regulates the tumor suppressor, interleukin-24, in human KB oral cancer cells. Mol Cell 35(1):17-24. https://doi.org/10.1007/s10059-013-2154-7

178. O'Connell RM, Taganov KD, Boldin MP, Cheng G, Baltimore D (2007) MicroRNA-155 is induced during the macrophage inflammatory response. Proc Natl Acad Sci U S A 104(5):1604-1609. https://doi.org/10.1073/pnas.0610731104

179. Ma X, Becker Buscaglia LE, Barker JR, Li Y (2011) MicroRNAs in NF-KB signaling. J Mol Cell Biol 3(3):159-166. https://doi.org/ 10.1093/jmcb/mjr007

180. Sun X, Icli B, Wara AK, Belkin N, He S, Kobzik L, Hunninghake GM, Vera MP et al (2012) MicroRNA-181b regulates NFkappaB-mediated vascular inflammation. J Clin Invest 122(6): 1973-1990. https://doi.org/10.1172/jci61495

181. Iliopoulos D, Jaeger SA, Hirsch HA, Bulyk ML, Struhl K (2010) STAT3 activation of miR-21 and miR-181b-1, via PTEN and CYLD, are part of the epigenetic switch linking inflammation to cancer. Mol Cell 39(4):493-506. https://doi.org/10.1016/j.molcel. 2010.07.023

182. Lukiw WJ, Zhao Y, Cui JG (2008) An NF-kappaB-sensitive micro RNA-146a-mediated inflammatory circuit in Alzheimer disease and in stressed human brain cells. J Biol Chem 283(46):3131531322. https://doi.org/10.1074/jbc.M805371200

183. Cui JG, Li YY, Zhao Y, Bhattacharjee S, Lukiw WJ (2010) Differential regulation of interleukin-1 receptor-associated kinase-1 (IRAK-1) and IRAK-2 by microRNA-146a and NFkappaB in stressed human astroglial cells and in Alzheimer disease. J Biol Chem 285(50):38951-38960. https://doi.org/10.1074/ jbc.M110.178848

184. Alexandrov PN, Zhao Y, Jones BM, Bhattacharjee S, Lukiw WJ (2013) Expression of the phagocytosis-essential protein TREM2 is down-regulated by an aluminum-induced miRNA-34a in a murine microglial cell line. J Inorg Biochem 128:267-269. https:// doi.org/10.1016/j.jinorgbio.2013.05.010

185. Devier DJ, Lovera JF, Lukiw WJ (2015) Increase in NF-kBsensitive miRNA-146a and miRNA-155 in multiple sclerosis (MS) and pro-inflammatory neurodegeneration. Front Mol Neurosci 8:5. https://doi.org/10.3389/fnmol.2015.00005

186. Yarbrough ML, Mata MA, Sakthivel R, Fontoura BM (2014) Viral subversion of nucleocytoplasmic trafficking. Traffic 
(Copenhagen, Denmark) 15(2):127-140. https://doi.org/10.1111/ tra. 12137

187. Li L, Chen XP, Li YJ (2010) MicroRNA-146a and human disease. Scand J Immunol 71(4):227-231. https://doi.org/10.1111/j.13653083.2010.02383.x

188. Li-Tempel T, Larra MF, Sandt E, Meriaux SB, Schote AB, Schachinger H, Muller CP, Turner JD (2016) The cardiovascular and hypothalamus-pituitary-adrenal axis response to stress is controlled by glucocorticoid receptor sequence variants and promoter methylation. Clin Epigenetics 8:12. https://doi.org/10.1186/ s13148-016-0180-y

189. Kumsta R, Entringer S, Koper JW, van Rossum EF, Hellhammer DH, Wust S (2007) Sex specific associations between common glucocorticoid receptor gene variants and hypothalamus-pituitaryadrenal axis responses to psychosocial stress. Biol Psychiatry 62(8):863-869. https://doi.org/10.1016/j.biopsych.2007.04.013

190. Derijk RH, de Kloet ER (2008) Corticosteroid receptor polymorphisms: determinants of vulnerability and resilience. Eur J Pharmacol 583(2-3):303-311. https://doi.org/10.1016/j.ejphar. 2007.11.072

191. Spijker AT, van Rossum EF (2009) Glucocorticoid receptor polymorphisms in major depression. Focus on glucocorticoid sensitivity and neurocognitive functioning. Ann N Y Acad Sci 1179:199215. https://doi.org/10.1111/j.1749-6632.2009.04985.x

192. Manenschijn L, van den Akker EL, Lamberts SW, van Rossum EF (2009) Clinical features associated with glucocorticoid receptor polymorphisms. An overview. Ann N Y Acad Sci 1179:179198. https://doi.org/10.1111/j.1749-6632.2009.05013.x

193. van Rossum EF, de Jong FJ, Koper JW, Uitterlinden AG, Prins ND, van Dijk EJ, Koudstaal PJ, Hofman A et al (2008) Glucocorticoid receptor variant and risk of dementia and white matter lesions. Neurobiol Aging 29(5):716-723. https://doi.org/ 10.1016/j.neurobiolaging.2006.11.016

194. van Rossum EF, Lamberts SW (2004) Polymorphisms in the glucocorticoid receptor gene and their associations with metabolic parameters and body composition. Recent Prog Horm Res 59: $333-357$

195. van den Akker EL, Koper JW, van Rossum EF, Dekker MJ, Russcher H, de Jong FH, Uitterlinden AG, Hofman A et al (2008) Glucocorticoid receptor gene and risk of cardiovascular disease. Arch Intern Med 168(1):33-39. https://doi.org/10.1001/ archinternmed.2007.41

196. Lian Y, Xiao J, Wang Q, Ning L, Guan S, Ge H, Li F, Liu J (2014) The relationship between glucocorticoid receptor polymorphisms, stressful life events, social support, and post-traumatic stress disorder. BMC Psychiatry 14:232. https://doi.org/10.1186/s12888014-0232-9

197. de Quervain DJ, Poirier R, Wollmer MA, Grimaldi LM, Tsolaki M, Streffer JR, Hock C, Nitsch RM et al (2004) Glucocorticoidrelated genetic susceptibility for Alzheimer's disease. Hum Mol Genet 13(1):47-52. https://doi.org/10.1093/hmg/ddg361

198. Nair S, Lee YH, Lindsay RS, Walker BR, Tataranni PA, Bogardus C, Baier LJ, Permana PA (2004) 11beta-hydroxysteroid dehydrogenase type 1: genetic polymorphisms are associated with type 2 diabetes in Pima Indians independently of obesity and expression in adipocyte and muscle. Diabetologia 47(6):1088-1095. https:// doi.org/10.1007/s00125-004-1407-6

199. Silverman MN, Pearce BD, Biron CA, Miller AH (2005) Immune modulation of the hypothalamic-pituitary-adrenal (HPA) axis during viral infection. Viral Immunol 18(1):41-78. https://doi.org/10. 1089/vim.2005.18.41

200. Jacobson L (2005) Hypothalamic-pituitary-adrenocortical axis regulation. Endocrinol Metab Clin N Am 34(2):271-292, vii. https://doi.org/10.1016/j.ecl.2005.01.003

201. Needham BL, Smith JA, Zhao W, Wang X, Mukherjee B, Kardia SL, Shively CA, Seeman TE et al (2015) Life course socioeconomic status and DNA methylation in genes related to stress reactivity and inflammation: the multi-ethnic study of atherosclerosis. Epigenetics 10(10):958-969. https://doi.org/10. 1080/15592294.2015.1085139

202. Zannas AS, Wiechmann T, Gassen NC, Binder EB (2016) Genestress-epigenetic regulation of FKBP5: clinical and translational implications. Neuropsychopharmacology 41(1):261-274. https:// doi.org/10.1038/npp.2015.235

203. Yehuda R, Daskalakis NP, Bierer LM, Bader HN, Klengel T, Holsboer F, Binder EB (2016) Holocaust exposure induced intergenerational effects on FKBP5 methylation. Biol Psychiatry 80(5):372-380. https://doi.org/10.1016/j.biopsych.2015.08.005

204. Turecki G, Meaney MJ (2016) Effects of the social environment and stress on glucocorticoid receptor gene methylation: a systematic review. Biol Psychiatry 79(2):87-96. https://doi.org/10.1016/ j.biopsych.2014.11.022

205. Argentieri MA, Nagarajan S, Seddighzadeh B, Baccarelli AA, Shields AE (2017) Epigenetic pathways in human disease: the impact of DNA methylation on stress-related pathogenesis and current challenges in biomarker development. EBioMedicine 18(Supplement C): 327-350. https://doi.org/10.1016/j.ebiom.2017.03.044

206. Klengel T, Pape J, Binder EB, Mehta D (2014) The role of DNA methylation in stress-related psychiatric disorders. Neuropharmacology 80:115-132. https://doi.org/10.1016/j. neuropharm.2014.01.013

207. Hogg K, Price EM, Robinson WP (2014) Improved reporting of DNA methylation data derived from studies of the human placenta. Epigenetics 9(3):333-337. https://doi.org/10.4161/epi.27648

208. Vinkers CH, Kalafateli AL, Rutten BP, Kas MJ, Kaminsky Z, Turner JD, Boks MP (2015) Traumatic stress and human DNA methylation: a critical review. Epigenomics 7(4):593-608. https:// doi.org/10.2217/epi.15.11

209. Michels KB, Binder AM, Dedeurwaerder S, Epstein CB, Greally JM, Gut I, Houseman EA, Izzi B et al (2013) Recommendations for the design and analysis of epigenome-wide association studies. Nat Methods 10(10):949-955. https://doi.org/10.1038/nmeth. 2632

210. Birney E, Smith GD, Greally JM (2016) Epigenome-wide association studies and the interpretation of disease-omics. PLoS Genet 12(6):e1006105. https://doi.org/10.1371/journal.pgen.1006105

211. Siegfried Z, Simon I (2010) DNA methylation and gene expression. Wiley Interdiscip Rev Syst Biol Med 2(3):362-371. https:// doi.org/10.1002/wsbm.64

212. Fries GR, Vasconcelos-Moreno MP, Gubert C, dos Santos BT, Sartori J, Eisele B, Ferrari P, Fijtman A et al (2014) Hypothalamic-pituitary-adrenal axis dysfunction and illness progression in bipolar disorder. Int $\mathbf{J}$ Neuropsychopharmacol 18(1). https://doi.org/10.1093/ijnp/pyu043

213. Leenen FAD, Muller CP, Turner JD (2016) DNA methylation: conducting the orchestra from exposure to phenotype? Clin Epigenetics 8(1):92. https://doi.org/10.1186/s13148-016-0256-8

214. Melas PA, Wei Y, Wong CC, Sjoholm LK, Aberg E, Mill J, Schalling M, Forsell Y et al (2013) Genetic and epigenetic associations of MAOA and NR3C1 with depression and childhood adversities. Int J Neuropsychopharmacol 16(7):1513-1528. https://doi.org/10.1017/s1461145713000102

215. Hohne N, Poidinger M, Merz F, Pfister H, Bruckl T, Zimmermann P, Uhr M, Holsboer F et al (2014) FKBP5 genotype-dependent DNA methylation and mRNA regulation after psychosocial stress in remitted depression and healthy controls. Int J Neuropsychopharmacol 18(4). https://doi.org/10.1093/ijnp/ pyu087

216. Miller AH, Raison CL (2016) The role of inflammation in depression: from evolutionary imperative to modern treatment target. Nat Rev Immunol 16(1):22-34. https://doi.org/10.1038/nri.2015.5 
217. Ferland CL, Harris EP, Lam M, Schrader LA (2014) Facilitation of the HPA axis to a novel acute stress following chronic stress exposure modulates histone acetylation and the ERK/MAPK pathway in the dentate gyrus of male rats. Endocrinology 155(8): 2942-2952. https://doi.org/10.1210/en.2013-1918

218. Chandramohan Y, Droste SK, Arthur JS, Reul JM (2008) The forced swimming-induced behavioural immobility response involves histone $\mathrm{H} 3$ phospho-acetylation and c-Fos induction in dentate gyrus granule neurons via activation of the N-methyl-Daspartate/extracellular signal-regulated kinase/mitogen- and stress-activated kinase signalling pathway. Eur J Neurosci 27(10):2701-2713. https://doi.org/10.1111/j.1460-9568.2008. 06230.x

219. Pan-Vazquez A, Rye N, Ameri M, McSparron B, Smallwood G, Bickerdyke J, Rathbone A, Dajas-Bailador F et al (2015) Impact of voluntary exercise and housing conditions on hippocampal glucocorticoid receptor, miR-124 and anxiety. Mol Brain 8(1):1-12. https://doi.org/10.1186/s13041-015-0128-8

220. Shimizu S, Tanaka T, Takeda T $(2015,2015)$ The Kampo medicine Yokukansan decreases microRNA-18 expression and recovers glucocorticoid receptors protein expression in the hypothalamus of stressed mice. Biomed Res Int:797280. https://oi.org/10. $1155 / 2015 / 797280$

221. Vreugdenhil E, Verissimo CS, Mariman R, Kamphorst JT, Barbosa JS, Zweers T, Champagne DL, Schouten T et al (2009) MicroRNA 18 and 124a down-regulate the glucocorticoid receptor: implications for glucocorticoid responsiveness in the brain. Endocrinology 150(5):2220-2228. https://doi.org/10.1210/en. 2008-1335

222. Späth-Schwalbe E, Born J, Schrezenmeier H, Bornstein SR, Stromeyer P, Drechsler S, Fehm HL, Porzsolt F (1994) Interleukin-6 stimulates the hypothalamus-pituitaryadrenocortical axis in man. J Clin Endocrinol Metab 79(4): 1212-1214. https://doi.org/10.1210/jcem.79.4.7962296

223. Chesnokova V, Melmed S (2002) Minireview: neuro-immunoendocrine modulation of the hypothalamic-pituitary-adrenal (HPA) axis by gp130 signaling molecules. Endocrinology 143(5):1571-1574. https://doi.org/10.1210/endo.143.5.8861

224. Jaattela M, Ilvesmaki V, Voutilainen R, Stenman UH, Saksela E (1991) Tumor necrosis factor as a potent inhibitor of adrenocorticotropin-induced cortisol production and steroidogenic P450 enzyme gene expression in cultured human fetal adrenal cells. Endocrinology 128(1):623-629. https://doi.org/10.1210/ endo-128-1-623

225. Barney M, Call GB, Mcllmoil CJ, Husein OF, Adams A, Balls AG, Oliveira GK, Miner EC et al (2000) Stimulation by interleukin- 6 and inhibition by tumor necrosis factor of cortisol release from bovine adrenal zona fasciculata cells through their receptors. ENDO 13(3):369-377. https://doi.org/10.1385/endo: 13:3:369

226. Mikhaylova IV, Kuulasmaa T, Jääskeläinen J, Voutilainen R (2007) Tumor necrosis factor- $\alpha$ regulates steroidogenesis, apoptosis, and cell viability in the human adrenocortical cell line NCIH295R. Endocrinology 148(1):386-392. https://doi.org/10.1210/ en.2006-0726

227. Imrich R, Vlcek M, Kerlik J, Vogeser M, Kirchhoff F, Penesova A, Radikova Z, Lukac J et al (2012) Adrenal function in rheumatoid arthritis: a correlation with disease activity. Arthritis Res Ther 14(Suppl 1):P27. https://doi.org/10.1186/ar3628

228. Aringer M, Feierl E, Smolen J (2008) Cytokine blockade—a promising therapeutic option in SLE. Z Rheumatol 67:315-317

229. Reincke M, Heppner C, Petzke F, Allolio B, Arlt W, Mbulamberi D, Siekmann L, Vollmer D et al (1994) Impairment of adrenocortical function associated with increased plasma tumor necrosis factor-alpha and interleukin-6 concentrations in African trypanosomiasis. Neuroimmunomodulation 1(1):14-22. https:// doi.org/10.1159/000095930

230. Miller AH, Pariante CM, Pearce BD (1999) Effects of cytokines on glucocorticoid receptor expression and function. Glucocorticoid resistance and relevance to depression. Adv Exp Med Biol 461:107-116. https://doi.org/10.1007/978-0-58537970-8_7

231. Ratman D, Vanden Berghe W, Dejager L, Libert C, Tavernier J, Beck IM, De Bosscher K (2013) How glucocorticoid receptors modulate the activity of other transcription factors: a scope beyond tethering. Mol Cell Endocrinol 380(1-2):41-54. https://doi.org/10. 1016/j.mce.2012.12.014

232. Galliher-Beckley AJ, Cidlowski JA (2009) Emerging roles of glucocorticoid receptor phosphorylation in modulating glucocorticoid hormone action in health and disease. IUBMB Life 61(10): 979-986. https://doi.org/10.1002/iub.245

233. Cohen S, Janicki-Deverts D, Doyle WJ, Miller GE, Frank E, Rabin BS, Turner RB (2012) Chronic stress, glucocorticoid receptor resistance, inflammation, and disease risk. Proc Natl Acad Sci U S A 109(16):5995-5999. https://doi.org/10.1073/pnas. 1118355109

234. Pace TWW, Miller AH (2009) Cytokines and glucocorticoid receptor signaling: relevance to major depression. Ann N Y Acad Sci 1179:86-105. https://doi.org/10.1111/j.1749-6632.2009. 04984.x

235. Guerrero J, Gatica HA, Rodríguez M, Estay R, Goecke IA (2013) Septic serum induces glucocorticoid resistance and modifies the expression of glucocorticoid isoforms receptors: a prospective cohort study and in vitro experimental assay. Crit Care 17(3):R107R107. https://doi.org/10.1186/cc12774

236. Spiers JG, Chen H-JC, Sernia C, Lavidis NA (2014) Activation of the hypothalamic-pituitary-adrenal stress axis induces cellular oxidative stress. Front Neurosci 8:456. https://doi.org/10.3389/fnins. 2014.00456

237. Go Y-M, Jones DP (2010) Redox control systems in the nucleus: mechanisms and functions. Antioxid Redox Signal 13(4):489 509. https://doi.org/10.1089/ars.2009.3021

238. Schiavone S, Jaquet V, Trabace L, Krause K-H (2013) Severe life stress and oxidative stress in the brain: from animal models to human pathology. Antioxid Redox Signal 18(12):1475-1490. https://doi.org/10.1089/ars.2012.4720

239. Zhou Q-G, Zhu L-J, Chen C, Wu H-Y, Luo C-X, Chang L, Zhu DY (2011) Hippocampal neuronal nitric oxide synthase mediates the stress-related depressive behaviors of glucocorticoids by downregulating glucocorticoid receptor. J Neurosci 31(21): 7579-7590. https://doi.org/10.1523/jneurosci.0004-11.2011

240. Liu MY, Zhu LJ, Zhou QG (2013) Neuronal nitric oxide synthase is an endogenous negative regulator of glucocorticoid receptor in the hippocampus. Neurol Sci 34(7):1167-1172. https://doi.org/10. 1007/s10072-012-1213-8

241. Gadek-Michalska A, Tadeusz J, Rachwalska P, Bugajski J (2013) Cytokines, prostaglandins and nitric oxide in the regulation of stress-response systems. Pharmacol Rep 65(6):1655-1662

242. Maur DG, Pascuan CG, Genaro AM, Zorrilla-Zubilete MA (2015) Involvement of nitric oxide, neurotrophins and HPA axis in neurobehavioural alterations induced by prenatal stress. Adv Neurobiol 10:61-74. https://doi.org/10.1007/978-1-4939-137254

243. Bugajski J, Gadek-Michalska A, Bugajski AJ (2004) Nitric oxide and prostaglandin systems in the stimulation of hypothalamicpituitary-adrenal axis by neurotransmitters and neurohormones. J Physiol Pharmacol 55(4):679-703

244. Gadek-Michalska A, Tadeusz J, Rachwalska P, Bugajski J (2015) Chronic stress adaptation of the nitric oxide synthases and IL1 beta levels in brain structures and hypothalamic-pituitary- 
adrenal axis activity induced by homotypic stress. J Physiol Pharmacol 66(3):427-440

245. Bugajski AJ, Gadek-Michalska A, Bugajski J (2006) The involvement of nitric oxide and prostaglandins in the cholinergic stimulation of hypothalamie-pituitary-adrenal response during crowding stress. J Physiol Pharmacol 57(3):463-477

246. Marchetti B, Serra PA, Tirolo C, L'Episcopo F, Caniglia S, Gennuso F, Testa N, Miele E et al (2005) Glucocorticoid receptor-nitric oxide crosstalk and vulnerability to experimental parkinsonism: pivotal role for glia-neuron interactions. Brain Res Brain Res Rev 48(2):302-321. https://doi.org/10.1016/j. brainresrev.2004.12.030

247. Da J, Chen L, Hedenstierna G (2007) Nitric oxide up-regulates the glucocorticoid receptor and blunts the inflammatory reaction in porcine endotoxin sepsis. Crit Care Med 35(1):26-32. https:// doi.org/10.1097/01.ccm.0000250319.91575.bb

248. Duma D, Silva-Santos JE, Assreuy J (2004) Inhibition of glucocorticoid receptor binding by nitric oxide in endotoxemic rats. Crit Care Med 32(11):2304-2310

249. Galigniana MD, Piwien-Pilipuk G, Assreuy J (1999) Inhibition of glucocorticoid receptor binding by nitric oxide. Mol Pharmacol 55(2):317-323

250. Pajovic SB, Pejic S, Stojiljkovic V, Gavrilovic L, Dronjak S, Kanazir DT (2006) Alterations in hippocampal antioxidant enzyme activities and sympatho-adrenomedullary system of rats in response to different stress models. Physiol Res 55(4):453-460

251. Djordjevic J, Djordjevic A, Adzic M, Radojcic MB (2010) Chronic social isolation compromises the activity of both glutathione peroxidase and catalase in hippocampus of male wistar rats. Cell Mol Neurobiol 30(5):693-700. https://doi.org/10.1007/ s10571-009-9493-0

252. Moller M, Du Preez JL, Emsley R, Harvey BH (2011) Isolation rearing-induced deficits in sensorimotor gating and social interaction in rats are related to cortico-striatal oxidative stress, and reversed by sub-chronic clozapine administration. Eur Neuropsychopharmacol 21(6):471-483. https://doi.org/10.1016/ j.euroneuro.2010.09.006

253. Pall ML (2001) Common etiology of posttraumatic stress disorder, fibromyalgia, chronic fatigue syndrome and multiple chemical sensitivity via elevated nitric oxide/peroxynitrite. Med Hypotheses 57(2):139-145. https://doi.org/10.1054/mehy.2001. 1325

254. Hoge CW, McGurk D, Thomas JL, Cox AL, Engel CC, Castro CA (2008) Mild traumatic brain injury in U.S. soldiers returning from Iraq. N Engl J Med 358(5):453-463. https://doi.org/10.1056/ NEJMoa072972

255. Abu-Qare A, Abou-Donia M (2000) Increased 8-hydroxy-2'deoxyguanosine, a biomarker of oxidative DNA damage in rat urine following a single dermal dose of DEET (N, N-diethyl-mtoluamide), and permethrin, alone and in combination. Toxicol Lett 117(3):151-160

256. Hunt N, McHale S (2007) Psychosocial aspects of andrologic disease. Endocrinol Metab Clin N Am 36(2):521-531. https:// doi.org/10.1016/j.ecl.2007.03.001

257. Bukhtoyarov OV, Samarin DM (2009) Psychogenic carcinogenesis: carcinogenesis is without exogenic carcinogens. Med Hypotheses 73(4):531-536. https://doi.org/10.1016/j.mehy.2009. 06.004

258. Simsek S, Kaplan I, Uysal C, Yuksel T, Alaca R (2016) The levels of cortisol, oxidative stress, and DNA damage in the victims of childhood sexual abuse: a preliminary study. J Child Sex Abus 25(2):175-184. https://doi.org/10.1080/10538712.2016.1123790

259. Moraes JB, Maes M, Roomruangwong C, Bonifacio KL, Barbosa DS, Vargas HO, Anderson G, Kubera M et al (2018) In major affective disorders, early life trauma predict increased nitrooxidative stress, lipid peroxidation and protein oxidation and recurrence of major affective disorders, suicidal behaviors and a lowered quality of life. Metab Brain Dis 33(4):1081-1096. https:// doi.org/10.1007/s11011-018-0209-3

260. D'Elia ATD, Matsuzaka CT, Neto JBB, Mello MF, Juruena MF, Mello AF (2018) Childhood sexual abuse and indicators of immune activity: a systematic review. Front Psychiatry 9:354. https:// doi.org/10.3389/fpsyt.2018.00354

261. do Prado CH, Grassi-Oliveira R, Wieck A, Zaparte A, Filho LD, da Silva Morrone M, Moreira JC, Bauer ME (2016) The impact of childhood maltreatment on redox state: relationship with oxidative damage and antioxidant defenses in adolescents with no psychiatric disorder. Neurosci Lett 617:173-177. https://doi.org/10.1016/j. neulet.2016.01.062

262. Boeck C, Koenig AM, Schury K, Geiger ML, Karabatsiakis A, Wilker S, Waller C, Gundel H et al (2016) Inflammation in adult women with a history of child maltreatment: the involvement of mitochondrial alterations and oxidative stress. Mitochondrion 30: 197-207. https://doi.org/10.1016/j.mito.2016.08.006

263. Maes M, Congio A, Brum J, Bonifacio K, Barbosa D, Vargas H, Morris G, Puri B et al (2018) Early life trauma predicts affective phenomenology and the effects are partly mediated by staging coupled with lowered lipid-associated antioxidant defences. bioRxiv. https://doi.org/10.1101/397711

264. Schiavone S, Sorce S, Dubois-Dauphin M, Jaquet V, Colaianna M, Zotti M, Cuomo V, Trabace L et al (2009) Involvement of NOX2 in the development of behavioral and pathologic alterations in isolated rats. Biol Psychiatry 66(4):384-392. https://doi.org/10. 1016/j.biopsych.2009.04.033

265. Heumuller S, Wind S, Barbosa-Sicard E, Schmidt HH, Busse R, Schroder K, Brandes RP (2008) Apocynin is not an inhibitor of vascular NADPH oxidases but an antioxidant. Hypertension 51(2):211-217. https://doi.org/10.1161/hypertensionaha.107. 100214

266. Wilkinson BL, Landreth GE (2006) The microglial NADPH oxidase complex as a source of oxidative stress in Alzheimer's disease. J Neuroinflammation 3(1):1-12. https://doi.org/10.1186/ 1742-2094-3-30

267. Di Filippo M, de Iure A, Giampà C, Chiasserini D, Tozzi A, Orvietani PL, Ghiglieri V, Tantucci M et al (2016) Persistent activation of microglia and NADPH oxidase drive hippocampal dysfunction in experimental multiple sclerosis. Sci Rep 6:20926. https://doi.org/10.1038/srep20926

268. Bermudez S, Khayrullina G, Zhao Y, Byrnes KR (2016) NADPH oxidase isoform expression is temporally regulated and may contribute to microglial/macrophage polarization after spinal cord injury. Mol Cell Neurosci 77:53-64. https://doi.org/10.1016/j.mcn. 2016.10.001

269. de Pablos RM, Herrera AJ, Espinosa-Oliva AM, Sarmiento M, Muñoz MF, Machado A, Venero JL (2014) Chronic stress enhances microglia activation and exacerbates death of nigral dopaminergic neurons under conditions of inflammation. $J$ Neuroinflammation 11(1):34. https://doi.org/10.1186/1742-209411-34

270. Tynan RJ, Naicker S, Hinwood M, Nalivaiko E, Buller KM, Pow DV, Day TA, Walker FR (2010) Chronic stress alters the density and morphology of microglia in a subset of stress-responsive brain regions. Brain Behav Immun 24(7):1058-1068. https://doi.org/10. 1016/j.bbi.2010.02.001

271. Calcia MA, Bonsall DR, Bloomfield PS, Selvaraj S, Barichello T, Howes OD (2016) Stress and neuroinflammation: a systematic review of the effects of stress on microglia and the implications for mental illness. Psychopharmacology 233(9):1637-1650. https://doi.org/10.1007/s00213-016-4218-9

272. Fonken LK, Frank MG, Kitt MM, D'Angelo HM, Norden DM, Weber MD, Barrientos RM, Godbout JP et al (2016) The alarmin HMGB1 mediates age-induced neuroinflammatory priming. J 
Neurosci 36(30):7946-7956. https://doi.org/10.1523/jneurosci. 1161-16.2016

273. Niraula A, Sheridan JF, Godbout JP (2017) Microglia priming with aging and stress. Neuropsychopharmacology 42(1):318333. https://doi.org/10.1038/npp.2016.185

274. Cunningham C (2013) Microglia and neurodegeneration: the role of systemic inflammation. Glia 61:71-90

275. Mayhew J, Beart PM, Walker FR (2015) Astrocyte and microglial control of glutamatergic signalling: a primer on understanding the disruptive role of chronic stress. J Neuroendocrinol 27(6):498 506. https://doi.org/10.1111/jne. 12273

276. Paolicelli RC, Ferretti MT (2017) Function and dysfunction of microglia during brain development: consequences for synapses and neural circuits. Front Synaptic Neurosci 9:9. https://doi.org/ 10.3389/fnsyn.2017.00009

277. Kumar A, Rinwa P, Kaur G, Machawal L (2013) Stress: neurobiology, consequences and management. J Pharm Bioallied Sci 5(2): 91-97. https://doi.org/10.4103/0975-7406.111818

278. Albrecht P, Lewerenz J, Dittmer S, Noack R, Maher P, Methner A (2010) Mechanisms of oxidative glutamate toxicity: the glutamate/cystine antiporter system xc- as a neuroprotective drug target. CNS Neurol Disord Drug Targets 9(3):373-382

279. Nguyen D, Alavi MV, Kim KY, Kang T, Scott RT, Noh YH, Lindsey JD, Wissinger B et al (2011) A new vicious cycle involving glutamate excitotoxicity, oxidative stress and mitochondrial dynamics. Cell Death Dis 2:e240. https://doi.org/10.1038/cddis. 2011.117

280. Chiappelli J, Rowland LM, Notarangelo FM, Wijtenburg SA, Thomas MAR, Pocivavsek A, Jones A, Wisner K et al (2018) Salivary kynurenic acid response to psychological stress: inverse relationship to cortical glutamate in schizophrenia. Neuropsychopharmacology. https://doi.org/10.1038/s41386018-0072-2

281. Popoli M, Yan Z, McEwen B, Sanacora G (2011) The stressed synapse: the impact of stress and glucocorticoids on glutamate transmission. Nat Rev Neurosci 13(1):22-37. https://doi.org/10. $1038 / \mathrm{nrn} 3138$

282. Lowy MT, Gault L, Yamamoto BK (1993) Adrenalectomy attenuates stress-induced elevations in extracellular glutamate concentrations in the hippocampus. J Neurochem 61(5):1957-1960

283. Moghaddam B (1993) Stress preferentially increases extraneuronal levels of excitatory amino acids in the prefrontal cortex: comparison to hippocampus and basal ganglia. J Neurochem 60(5):1650-1657

284. Sagara Y, Schubert D (1998) The activation of metabotropic glutamate receptors protects nerve cells from oxidative stress. J Neurosci 18(17):6662-6671

285. Evanson NK, Herman JP (2015) Metabotropic glutamate receptormediated signaling dampens the HPA axis response to restraint stress. Physiol Behav 150:2-7. https://doi.org/10.1016/j.physbeh. 2015.02.027

286. Zannas AS, West AE (2014) Epigenetics and the regulation of stress vulnerability and resilience. Neuroscience 264:157-170. https://doi.org/10.1016/j.neuroscience.2013.12.003

287. O'Leary OF, Felice D, Galimberti S, Savignac HM, Bravo JA, Crowley T, El Yacoubi M, Vaugeois J-M et al (2014) $\mathrm{GABA}(\mathrm{B}(1))$ receptor subunit isoforms differentially regulate stress resilience. Proc Natl Acad Sci 111(42):15232-15237. https://doi.org/10.1073/pnas.1404090111

288. Peedicayil J (2015) Epigenetics as a link between psychosocial factors and mental disorders. Indian J Psychiatry 57(2):218-218. https://doi.org/10.4103/0019-5545.158208

289. Schiele MA, Domschke K (2018) Epigenetics at the crossroads between genes, environment and resilience in anxiety disorders. Genes Brain Behav 17(3):e12423. https://doi.org/10.1111/gbb. 12423
290. Picard M, McEwen BS (2018) Psychological Stress and Mitochondria: a systematic review. Psychosom Med 80(2):141153. https://doi.org/10.1097/psy.0000000000000545

291. Liu W, Zhou C (2012) Corticosterone reduces brain mitochondrial function and expression of mitofusin, BDNF in depression-like rodents regardless of exercise preconditioning. Psychoneuroendocrinology 37(7):1057-1070. https://doi.org/ 10.1016/j.psyneuen.2011.12.003

292. Madrigal JL, Olivenza R, Moro MA, Lizasoain I, Lorenzo P, Rodrigo J, Leza JC (2001) Glutathione depletion, lipid peroxidation and mitochondrial dysfunction are induced by chronic stress in rat brain. Neuropsychopharmacology 24(4):420-429. https:// doi.org/10.1016/s0893-133x(00)00208-6

293. Rezin GT, Cardoso MR, Goncalves CL, Scaini G, Fraga DB, Riegel RE, Comim CM, Quevedo J et al (2008) Inhibition of mitochondrial respiratory chain in brain of rats subjected to an experimental model of depression. Neurochem Int 53(6-8):395400. https://doi.org/10.1016/j.neuint.2008.09.012

294. Vicario M, Alonso C, Guilarte M, Serra J, Martinez C, GonzalezCastro AM, Lobo B, Antolin M et al (2012) Chronic psychosocial stress induces reversible mitochondrial damage and corticotropinreleasing factor receptor type-1 upregulation in the rat intestine and IBS-like gut dysfunction. Psychoneuroendocrinology 37(1): 65-77. https://doi.org/10.1016/j.psyneuen.2011.05.005

295. Chen YJ, Huang F, Zhang M, Shang HY (2010) Psychological stress alters ultrastructure and energy metabolism of masticatory muscle in rats. J Biomed Biotechnol 2010:302693. https://doi.org/ $10.1155 / 2010 / 302693$

296. Roosevelt TS, Ruhmann-Wennhold A, Nelson DH (1973) Adrenal corticosteroid effects upon rat brain mitochondrial metabolism. Endocrinology 93(3):619-625. https://doi.org/10.1210/ endo-93-3-619

297. Lambertini L, Chen J, Nomura Y (2015) Mitochondrial gene expression profiles are associated with maternal psychosocial stress in pregnancy and infant temperament. PLoS One 10(9):e0138929. https://doi.org/10.1371/journal.pone.0138929

298. Hunter RG, Seligsohn M, Rubin TG, Griffiths BB, Ozdemir Y, Pfaff DW, Datson NA, McEwen BS (2016) Stress and corticosteroids regulate rat hippocampal mitochondrial DNA gene expression via the glucocorticoid receptor. Proc Natl Acad Sci U S A 113(32):9099-9104. https://doi.org/10.1073/pnas.1602185113

299. Garcia-Fernandez M, Castilla-Ortega E, Pedraza C, Blanco E, Hurtado-Guerrero I, Barbancho MA, Chun J, Rodriguez-deFonseca $\mathrm{F}$ et al (2012) Chronic immobilization in the malparl knockout mice increases oxidative stress in the hippocampus. Int J Neurosci 122(10):583-589. https://doi.org/10.3109/00207454. 2012.693998

300. Johnson CH, Ivanisevic J, Siuzdak G (2016) Metabolomics: beyond biomarkers and towards mechanisms. Nat Rev Mol Cell Biol 17(7):451-459. https://doi.org/10.1038/nrm.2016.25

301. Tian JS, Xia XT, Wu YF, Zhao L, Xiang H, Du GH, Zhang X, Qin XM (2016) Discovery, screening and evaluation of a plasma biomarker panel for subjects with psychological suboptimal health state using (1)H-NMR-based metabolomics profiles. Sci Rep 6: 33820. https://doi.org/10.1038/srep33820

302. Filiou MD, Zhang Y, Teplytska L, Reckow S, Gormanns P, Maccarrone G, Frank E, Kessler MS et al (2011) Proteomics and metabolomics analysis of a trait anxiety mouse model reveals divergent mitochondrial pathways. Biol Psychiatry 70(11):10741082. https://doi.org/10.1016/j.biopsych.2011.06.009

303. Fan X, Li D, Lichti CF, Green TA (2013) Dynamic proteomics of nucleus accumbens in response to acute psychological stress in environmentally enriched and isolated rats. PLoS One 8(9): e73689. https://doi.org/10.1371/journal.pone.0073689

304. Brunst KJ, Sanchez Guerra M, Gennings C, Hacker M, Jara C, Bosquet Enlow M, Wright RO, Baccarelli A et al (2017) Maternal 
lifetime stress and prenatal psychological functioning and decreased placental mitochondrial DNA copy number in the PRISM study. Am J Epidemiol 186(11):1227-1236. https://doi. org/10.1093/aje/kwx183

305. Wang D, Li Z, Liu W, Zhou J, Ma X, Tang J, Chen X (2018) Differential mitochondrial DNA copy number in three mood states of bipolar disorder. BMC Psychiatry 18(1):149. https://doi.org/10. 1186/s12888-018-1717-8

306. Berger M, Juster R-P, Sarnyai Z (2015) Mental health consequences of stress and trauma: allostatic load markers for practice and policy with a focus on indigenous health. Australas Psychiatry 23(6):644-649. https://doi.org/10.1177/1039856215608281

307. Wellen KE, Hatzivassiliou G, Sachdeva UM, Bui TV, Cross JR, Thompson CB (2009) ATP-citrate lyase links cellular metabolism to histone acetylation. Science 324(5930):1076-1080. https://doi. org/10.1126/science. 1164097

308. Martinez-Reyes I, Diebold LP, Kong H, Schieber M, Huang H, Hensley CT, Mehta MM, Wang T et al (2016) TCA cycle and mitochondrial membrane potential are necessary for diverse biological functions. Mol Cell 61(2):199-209. https://doi.org/10. 1016/j.molcel.2015.12.002

309. Klose RJ, Zhang Y (2007) Regulation of histone methylation by demethylimination and demethylation. Nat Rev Mol Cell Biol 8(4):307-318. https://doi.org/10.1038/nrm2143

310. Picard M (2015) Mitochondrial synapses: intracellular communication and signal integration. Trends Neurosci 38(8):468-474. https://doi.org/10.1016/j.tins.2015.06.001

311. Picard M, Juster RP, McEwen BS (2014) Mitochondrial allostatic load puts the 'gluc' back in glucocorticoids. Nat Rev Endocrinol 10(5):303-310. https://doi.org/10.1038/nrendo.2014.22

312. Bose HS, Lingappa VR, Miller WL (2002) Rapid regulation of steroidogenesis by mitochondrial protein import. Nature 417(6884):87-91. https://doi.org/10.1038/417087a

313. Midzak A, Papadopoulos V (2016) Adrenal mitochondria and steroidogenesis: from individual proteins to functional protein assemblies. Front Endocrinol (Lausanne) 7:106. https://doi.org/10. 3389/fendo.2016.00106

314. Psarra AM, Sekeris CE (2011) Glucocorticoids induce mitochondrial gene transcription in HepG2 cells: role of the mitochondrial glucocorticoid receptor. Biochim Biophys Acta 1813(10):1814 1821. https://doi.org/10.1016/j.bbamcr.2011.05.014

315. Psarra AM, Sekeris CE (2009) Glucocorticoid receptors and other nuclear transcription factors in mitochondria and possible functions. Biochim Biophys Acta 1787(5):431-436. https://doi.org/ 10.1016/j.bbabio.2008.11.011

316. Du J, McEwen B, Manji HK (2009) Glucocorticoid receptors modulate mitochondrial function: a novel mechanism for neuroprotection. Commun Integr Biol 2(4):350-352

317. Tome ME, Lee K, Jaramillo MC, Briehl MM (2012) Mitochondria are the primary source of the $\mathrm{H}(2) \mathrm{O}(2)$ signal for glucocorticoidinduced apoptosis of lymphoma cells. Exp Ther Med 4(2):237242. https://doi.org/10.3892/etm.2012.595

318. He Y, Zhang L, Zhu Z, Xiao A, Yu H, Gan X (2017) Blockade of cyclophilin $\mathrm{D}$ rescues dexamethasone-induced oxidative stress in gingival tissue. PLoS One 12(3):e0173270. https://doi.org/10. 1371/journal.pone. 0173270

319. Neuhaus JF, Baris OR, Hess S, Moser N, Schroder H, Chinta SJ, Andersen JK, Kloppenburg P et al (2014) Catecholamine metabolism drives generation of mitochondrial DNA deletions in dopaminergic neurons. Brain 137(Pt 2):354-365. https://doi.org/10. 1093/brain/awt291

320. Neuhaus JF, Baris OR, Kittelmann A, Becker K, Rothschild MA, Wiesner RJ (2017) Catecholamine metabolism induces mitochondrial DNA deletions and leads to severe adrenal degeneration during aging. Neuroendocrinology 104(1):72-84. https:// doi.org/10.1159/000444680

321. Gergalova G, Lykhmus O, Komisarenko S, Skok M (2014) Alpha7 nicotinic acetylcholine receptors control cytochrome c release from isolated mitochondria through kinase-mediated pathways. Int J Biochem Cell Biol 49:26-31. https://doi.org/10.1016/j. biocel.2014.01.001

322. Lykhmus O, Gergalova G, Koval L, Zhmak M, Komisarenko S, Skok M (2014) Mitochondria express several nicotinic acetylcholine receptor subtypes to control various pathways of apoptosis induction. Int J Biochem Cell Biol 53:246-252. https://doi.org/ 10.1016/j.biocel.2014.05.030

323. Morris G, Walker AJ, Berk M, Maes M, Puri BK (2017) Cell death pathways: a novel therapeutic approach for neuroscientists. Mol Neurobiol. https://doi.org/10.1007/s12035-017-0793-y

324. Lindqvist D, Fernstrom J, Grudet C, Ljunggren L, TraskmanBendz L, Ohlsson L, Westrin A (2016) Increased plasma levels of circulating cell-free mitochondrial DNA in suicide attempters: associations with HPA-axis hyperactivity. Transl Psychiatry 6(12): e971. https://doi.org/10.1038/tp.2016.236

325. Trumpff C, Marsland AL, Basualto-Alarcon C, Martin JL, Carroll JE, Sturm G, Vincent AE, Mosharov EV et al (2018) Acute psychological stress triggers circulating cell-free mitochondrial DNA. bioRxiv. https://doi.org/10.1101/405886

326. Kuck JL, Obiako BO, Gorodnya OM, Pastukh VM, Kua J, Simmons JD, Gillespie MN (2015) Mitochondrial DNA damage-associated molecular patterns mediate a feed-forward cycle of bacteria-induced vascular injury in perfused rat lungs. Am J Phys Lung Cell Mol Phys 308(10):L1078-L1085. https://doi.org/ 10.1152/ajplung.00015.2015

327. Grazioli S, Pugin J (2018) Mitochondrial damage-associated molecular patterns: from inflammatory signaling to human diseases. Front Immunol 9(832). https://doi.org/10.3389/fimmu.2018. 00832

328. Bliksoen M, Mariero LH, Torp MK, Baysa A, Ytrehus K, Haugen F, Seljeflot I, Vaage J et al (2016) Extracellular mtDNA activates NF-kappaB via toll-like receptor 9 and induces cell death in cardiomyocytes. Basic Res Cardiol 111(4):42. https://doi.org/10. 1007/s00395-016-0553-6

329. Zhang JZ, Liu Z, Liu J, Ren JX, Sun TS (2014) Mitochondrial DNA induces inflammation and increases TLR9/NF-kappaB expression in lung tissue. Int J Mol Med 33(4):817-824. https://doi. org/10.3892/ijmm.2014.1650

330. Watanabe Y, Nagai Y, Takatsu K (2013) Activation and regulation of the pattern recognition receptors in obesity-induced adipose tissue inflammation and insulin resistance. Nutrients 5(9):37573778. https://doi.org/10.3390/nu5093757

331. Huang S, Rutkowsky JM, Snodgrass RG, Ono-Moore KD, Schneider DA, Newman JW, Adams SH, Hwang DH (2012) Saturated fatty acids activate TLR-mediated proinflammatory signaling pathways. J Lipid Res 53(9):2002-2013. https://doi.org/10. 1194/jlr.D029546

332. Hu R, Xia CQ, Butfiloski E, Clare-Salzler M (2018) Effect of high glucose on cytokine production by human peripheral blood immune cells and type I interferon signaling in monocytes: implications for the role of hyperglycemia in the diabetes inflammatory process and host defense against infection. Clin Immunol 195: 139-148. https://doi.org/10.1016/j.clim.2018.06.003

333. Hoeijmakers L, Heinen Y, van Dam A-M, Lucassen PJ, Korosi A (2016) Microglial priming and Alzheimer's disease: a possible role for (early) immune challenges and epigenetics? Front Hum Neurosci 10:398. https://doi.org/10.3389/fnhum.2016.00398 